\title{
Multiscale variability of amphipod assemblages in Posidonia oceanica meadows
}

\author{
Nicolas Sturaro *, Gilles Lepoint, Simon Vermeulen, Sylvie Gobert \\ Laboratory of Oceanology, MARE Centre, University of Liège, Allée du Six Août 13, building B6c (Sart Tilman), 4000 Liège, Belgium
}

\section{A R T I C L E I N F O}

\section{Article history:}

Received 17 May 2013

Received in revised form 27 April 2014

Accepted 29 April 2014

Available online 9 May 2014

\section{Keywords:}

Amphipod assemblages

Posidonia oceanica

Seagrass

Hierarchical sampling design

Mediterranean Sea

\begin{abstract}
A B S T R A C T
The study of spatial patterns is important in understanding the causes of the distribution and abundance of organisms, and it also provides a valuable basis for management and conservation. Amphipod crustaceans are key organisms in seagrass ecosystems. However, little attention has been paid to the spatial scales at which amphipod assemblages may vary. We examined variability patterns of amphipod populations inhabiting Posidonia oceanica meadows, over spatial scales spanning four orders of magnitude (1 to 1000 meters) and for two consecutive years. This study reports the scales that contributed most to spatial variation of amphipod assemblages and explores the potential processes driving the observed patterns, with particular emphasis on habitat features. The number of species, the diversity, and the density of some species varied substantially across years. For most species the highest spatial variation in density and biomass occurred at small scales ( 1 and 10 meters). Based on density data, the structure of amphipod assemblages did not differ at any scales investigated. The patchiness that occurred at small scales may have been related to habitat features, but only weakly. Instead, we postulate that amphipod behavioral processes likely represent good explanatory factors. Although, small-scale spatial variability can be an important feature of amphipod assemblages in $P$. oceanica meadows, some patterns may have gone undetected because they occur at scales smaller than those investigated.
\end{abstract}

(c) 2014 Elsevier B.V. All rights reserved.

\section{Introduction}

One of the main problems ecologists face is the inherent heterogeneity of ecosystems (Kolasa and Pickett, 1991; Levin, 1992). Natural populations are patchy at multiple spatial and temporal scales (Dayton and Tegner, 1984; Schneider, 1994), with greater fluctuation at some scales than others (Fraschetti et al., 2005; García-Charton et al., 2004). Accordingly, variability in the structure of assemblages appears more evident at some scales (Underwood and Chapman, 1996). This variability, especially at small scales, should not be disregarded as a bias or an impediment, but as valuable information in understanding ecosystems (Coleman, 2002; Fraschetti et al., 2005). The study of spatial patterns is crucial in order to elucidate processes that determine the distribution and abundance of organisms, and provides a basis for management and conservation (Levin, 1992).

Nested hierarchical sampling designs are powerful tools to help sort out spatial patterns, and ensure appropriate replication (Underwood, 1997). The spatial scale of observation is methodologically based on the decision of observers and not on inherent characteristics of ecological processes (Allen and Hoekstra, 1991). Observed patterns are the

\footnotetext{
* Corresponding author. Tel.: + 3243664829.

E-mail address: nicolas.sturaro@ulg.ac.be (N. Sturaro).
}

result of different factors operating over a hierarchy of spatial scales (Wiens, 1989). Investigating patterns at multiple and simultaneous scales facilitates the identification of relevant scales of natural variability, and developing hypotheses regarding potential factors that determine spatial patchiness. This knowledge can help in selecting the most appropriate sampling scales in the design and interpretation of monitoring programs. Such methodology can save massive energy and cost by avoiding studies that cannot address relevant processes (Underwood, 1997).

In the Mediterranean Sea, the endemic seagrass Posidonia oceanica (L.) Delile forms large meadows with widely recognized ecological and economic roles (Boudouresque et al., 2006). These meadows are important habitats for a large number of species, including amphipod crustaceans (Gambi et al., 1992; Mazzella et al., 1989). Amphipods are important food sources for higher level predators such as fishes (Bell and Harmelin-Vivien, 1983; Pinnegar and Polunin, 2000) and possibly decapods (Lepoint et al., 2000; Vizzini et al., 2002). They are also sensitive to anthropogenic and natural disturbances (Conlan, 1994; Thomas, 1993) and are widely considered good potential indicators of ecosystem degradation (Conradi et al., 1997; Guerra-García and García-Gómez, 2001), notably in P. oceanica meadows (Sánchez-Jerez et al., 2000). These meadows, characterized by large heterogeneity at small and medium scales (Balestri et al., 2003; Gobert et al., 2003; Panayotidis et al., 1981; Zupo et al., 2006), could influence variability of amphipod assemblages. 
Bathymetric and seasonal patterns of amphipod assemblages associated with $P$. oceanica meadows have been extensively studied (Gambi et al., 1992; Mazzella et al., 1989; Scipione and Fresi, 1984; ZakhamaSraieb et al., 2011), along with other factors. However, spatial variability of amphipod assemblages at multiple scales in P. oceanica meadows has never been described in detail, despite its importance in community ecology (Underwood, 1997).

At large scales (seagrass landscapes), the position of meadows in a bay, adjacent habitats, as well as hydro-climatic forcing and environmental anthropogenic/natural disturbances all likely influence the distribution of macrozoobenthic assemblages (Bell et al., 2006; Gillanders, 2006). At small to intermediate scales, the structure of habitat (with resources such as food and shelter) is more likely to drive much of their variability (Gillanders, 2006). Studies have investigated the potential importance of temperate seagrass features on the distribution of small macrozoobenthic organisms (Attrill et al., 2000; Connolly, 1995; Edgar and Robertson, 1992; Worthington et al., 1992), including amphipod crustaceans (Como et al., 2008; González et al., 2008; Sánchez-Jerez et al., 2000). For instance, densities of several species correlated strongly with seagrass biomass (Attrill et al., 2000; González et al., 2008), epiphytes (Schneider and Mann, 1991; Zakhama-Sraieb et al., 2011) and detritus (Como et al., 2008; Sánchez-Jerez et al., 2000). Other factors such as recruitment, competition, and predation also act at multiple spatial scales (Gillanders, 2006; Turner et al., 1999). The main challenge remains in evaluating the relative importance of such processes, the scale at which they act, and the way they influence the structure of assemblages (Menge and Farrell, 1989).

This study is based on a hierarchical sampling design conducted for two consecutive years. Our objectives are to: (1) examine the variability patterns of amphipod assemblages in $P$. oceanica meadows over spatial scales spanning four orders of magnitude ( 1 to 1000 meters); (2) identify the scales at which most spatial variation was observed in order to provide clues on potentially important determinants of these assemblages; and (3) explore the relationships between amphipod and habitat variables.

\section{Materials and methods}

\subsection{Study area}

The study was carried out in the Revellata Bay (Corsica, Northwestern Mediterranean Sea; $42^{\circ} 34^{\prime} \mathrm{N}, 8^{\circ} 44^{\prime} \mathrm{E}$; Fig. 1) from the oceanographic station STARESO (Station de Recherches Sous-Marines et Océanographiques). The bay encompasses approximately $7.8 \mathrm{~km}$ of shoreline, fringed by 53 ha of rocky sublittoral habitat covered partially by photophilic macroalgae, 14 ha of sandy substrate and 179 ha of P. oceanica seagrass meadows (Sargian, 1997) that extend to depths of $40 \mathrm{~m}$ (Janssens, 2000). Local P. oceanica meadows have been described in detail elsewhere (Gobert, 2002). Surface temperatures range from $\sim 13{ }^{\circ} \mathrm{C}$ in February to $\sim 26{ }^{\circ} \mathrm{C}$ in August. The area supports a local population of about 5500 people that increases 10 -fold during summer tourism. Since 2008, Revellata Bay has been part of the Natura 2000 network, a centerpiece of the European Union nature and biodiversity policy (EC, 1992). Overall, the ecological status of seawater in this area is considered good (Gobert et al., 2009)

\subsection{Sampling design}

The study followed a hierarchical sampling design and focused on variability on 4 spatial scales, ranging from meters to 1000 s of meters within two zones of Revellata Bay (Fig. 1). For each zone, we chose 2 sites (separated by $\sim 100 \mathrm{~m}$ ), and then randomly selected 2 sectors (separated by $\sim 10 \mathrm{~m}$ ) within each site. Each sector was delimited by a permanent frame circumscribing an area of $9 \mathrm{~m}^{2}$, within which we collected 4 replicates separated by $\sim 1 \mathrm{~m}$. The study was conducted between 11 and $13 \mathrm{~m}$ depth, and between 10 am and $3 \mathrm{pm}$ (local time), to limit depth and diel variability. Sampling was performed in two consecutive years (August 2007 and 2008), to produce a total of 64 samples. Weather conditions (sunny and calm) were similar during the two sampling periods.

\subsection{Sample collection}

Amphipod samples were collected by scuba diving using an airlift (Bussers et al., 1983; Michel et al., 2010). The sampling areas of the meadow were delimited by a PVC cylinder (height: $48 \mathrm{~cm}$, diameter: $48.5 \mathrm{~cm}$ ) to prevent escape by mobile species. We suctioned a surface of $0.185 \mathrm{~m}^{2}$ continuously for 2 minutes under constant airflow, collecting amphipods and other invertebrates in a $0.5 \mathrm{~mm}$ mesh bag. Samples were sieved through a $0.5 \mathrm{~mm}$ mesh, fixed in a $4 \%$ formalin and seawater mix, and then transferred to $70 \%$ ethanol.

Amphipods were counted and identified to species level, using the handbook of Mediterranean amphipods (Ruffo et al., 1982, 1989, 1993, 1998), and available published literature in the case of new records. We estimated the relative abundance and frequency of
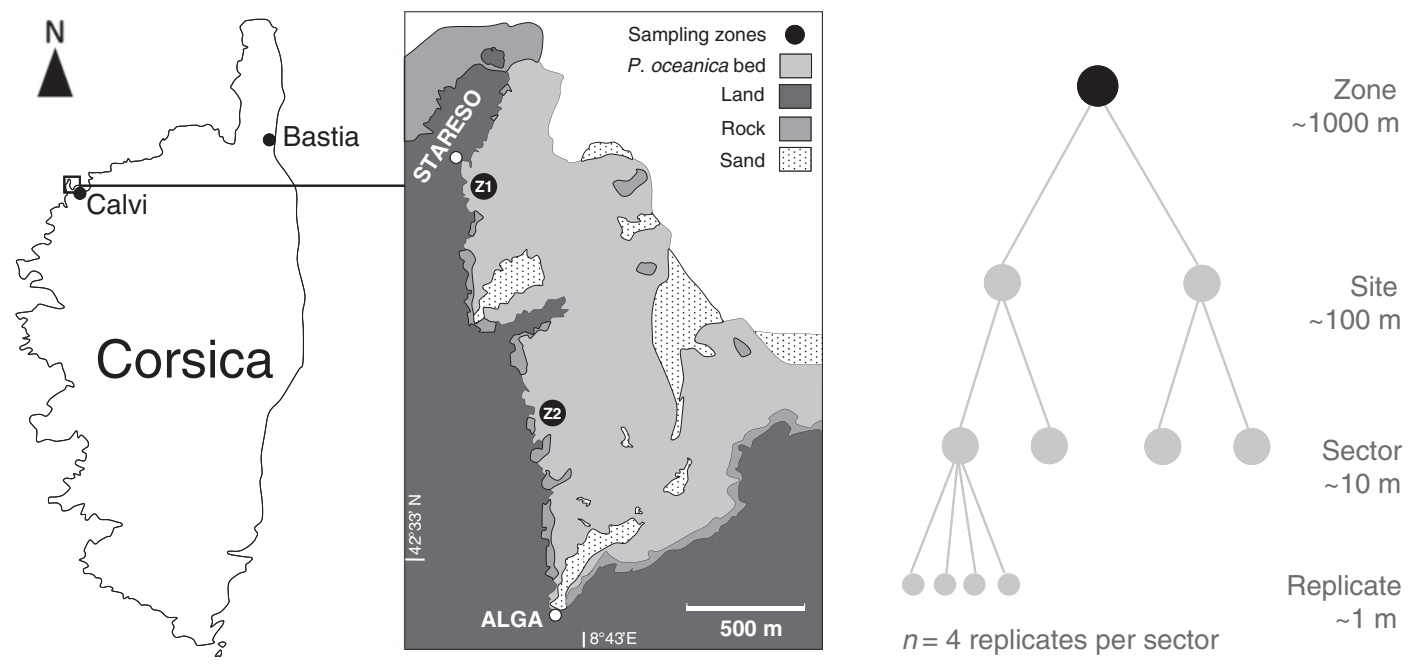

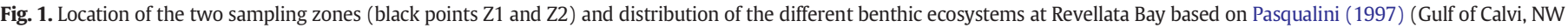

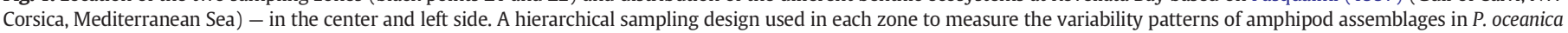
meadows, over spatial scales spanning four orders of magnitude (1 to 1000 meters) - right side. 
Table 1

Structure of the random model ANOVA used in the analysis of amphipod general descriptors, and densities/biomasses of amphipod taxa.

\begin{tabular}{|c|c|c|c|}
\hline Source & Abbreviation & $F$-ratio or quasi $F$-ratio & Variance component \\
\hline Year & Y & $\mathrm{MS}_{Y} / \mathrm{MS}_{Y \times Z}$ & $\left(\mathrm{MS}_{Y}-\mathrm{MS}_{Y \times Z}\right) / b c d n$ \\
\hline Zone & $Z$ & $\mathrm{MS}_{Z} /\left(\mathrm{MS}_{S(Z)}+\mathrm{MS}_{Y \times Z}-\mathrm{MS}_{Y \times S(Z))}\right)$ & $\left(\mathrm{MS}_{Z}-\mathrm{MS}_{S(Z)}-\mathrm{MS}_{Y \times Z}+\mathrm{MS}_{Y \times S(Z))}\right) / a c d n$ \\
\hline Site(zone) & $S(Z)$ & $\mathrm{MS}_{S(Z)} /\left(\mathrm{MS}_{\mathrm{Se}(S(Z))}+\mathrm{MS}_{Y \times S(Z)}-\mathrm{MS}_{Y \times \operatorname{Se}(S(Z))}\right)$ & $\left(\mathrm{MS}_{S(Z)}-\mathrm{MS}_{\mathrm{Se}(S(Z))}-\mathrm{MS}_{Y \times S(Z)}+\mathrm{MS}_{Y \times \operatorname{Se}(S(Z))}\right) / a d n$ \\
\hline Sector(site(zone)) & $\operatorname{Se}(S(Z))$ & $\mathrm{MS}_{\mathrm{Se}(S(Z))} / \mathrm{MS}_{Y \times \operatorname{Se}(S(Z))}$ & $\left(\mathrm{MS}_{\mathrm{Se}(S(Z))}-\mathrm{MS}_{Y \times \operatorname{Se}(S(Z))) / a n}\right.$ \\
\hline Year $\times$ zone & $Y \times Z$ & $\mathrm{MS}_{Y \times Z} / \mathrm{MS}_{Y \times S(Z)}$ & $\left(\mathrm{MS}_{Y \times Z}-\mathrm{MS}_{Y \times S(Z)}\right) / c d n$ \\
\hline Year $\times$ site (zone) & $Y \times S(Z)$ & $\mathrm{MS}_{Y \times S(Z)} / \mathrm{MS}_{Y \times \operatorname{Se}(S(Z))}$ & $\left(\mathrm{MS}_{Y \times S(Z)}-\mathrm{MS}_{Y \times \operatorname{Se}(S(Z))}\right) / d n$ \\
\hline Year $\times$ sector $($ site $($ zone $))$ & $Y \times \operatorname{Se}(S(Z))$ & 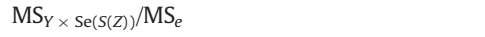 & $\left(\mathrm{MS}_{Y \times \mathrm{Se}(S(Z))}-\mathrm{MS}_{e}\right) / n$ \\
\hline Residual $=$ error & $e$ & & $\mathrm{MS}_{e}$ \\
\hline
\end{tabular}

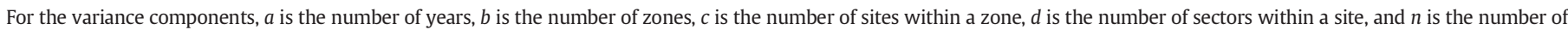
replicate samples in each combination of treatments. MS = mean square.

occurrence $(f)$ for each species. We also quantified density (individuals $\cdot \mathrm{m}^{-2}$ ) and biomass ( $\mathrm{mg}$ dry weight $\cdot \mathrm{m}^{-2}$; after drying at $60{ }^{\circ} \mathrm{C}$ for $48 \mathrm{~h}$ ) for each amphipod species. Amphipod assemblages were characterized using several descriptors: number of species $(S)$, Shannon-Wiener diversity index $\left(H^{\prime}\right)=-\sum_{i} p_{i} \log \left(p_{i}\right)$ where $p_{i}$ is the proportion of the total count arising from the $i$ th species, and
Pielou's evenness index $\left(J^{\prime}\right)=\frac{H^{\prime}}{\log S}$ where $S$ is the total number of species. Ovigerous females were counted for all species.

Habitat variables were quantified in 2008 to assess relationships with amphipod faunal variables. Shoot density (shoots $\mathrm{m}^{-2} ; n=4$ per sector) was measured in the general area where amphipods were previously sampled. Leaf litter material along with macrophyte debris

Table 2

Mean density (individuals $\cdot \mathrm{m}^{-2}$ ) of the amphipod taxa in the two zones in 2007 and 2008 (gaps indicates absent).

\begin{tabular}{|c|c|c|c|c|}
\hline & \multicolumn{2}{|c|}{ Zone 1} & \multicolumn{2}{|c|}{ Zone 2} \\
\hline & 2007 & 2008 & 2007 & 2008 \\
\hline \multicolumn{5}{|l|}{ Gammaridea } \\
\hline Ampeliscarubella (Costa, 1864) & & & • & • \\
\hline Ampithoehelleri (Karaman, 1975) & $\bullet$ & 0 & - & - \\
\hline Aora gracilis (Bate, 1857) & $\cdot$ & & & \\
\hline Aora spinicornis (Afonso, 1976) & O & 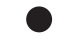 & 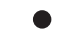 & ○ \\
\hline Apherusa chiereghinii (Giordani-Soika, 1950) & & & & C \\
\hline Apolochus neapolitanus (Della Valle, 1893) & - & 0 & $\bullet$ & - \\
\hline Atylus guttatus (Costa, 1851) & - & $\bullet$ & • & • \\
\hline Cymadusa crassicornis (Costa, 1853) & & & • & \\
\hline Dexamine spiniventris (Costa, 1853) & - & & $\bullet$ & $\bullet$ \\
\hline Dexamine spinosa (Montagu, 1813) & $\bullet$ & $\bullet$ & - & - \\
\hline Ericthonius punctatus (Bate, 1857) & & $\bullet$ & & - \\
\hline Eusiroides dellavallei (Chevreux, 1899) & $\bullet$ & $\bullet$ & $\bullet$ & $\cdot$ \\
\hline Gammarella fucicola (Leach, 1814) & • & • & & $\cdot$ \\
\hline Guernea coalita (Norman, 1868) & • & & & \\
\hline Hyale camptonyx (Heller, 1866) & & $\bullet$ & & \\
\hline Iphimedia minuta (Sars, 1882) & $\bullet$ & $\bullet$ & $\bullet$ & $\bullet$ \\
\hline \multicolumn{5}{|l|}{ Jassa ocia (Bate, 1862) } \\
\hline Leptocheirus guttatus (Grube, 1864) & & • & • & $\bullet$ \\
\hline Leucothoespinicarpa (Abildgaard, 1789) & & - & $\bullet$ & $\cdot$ \\
\hline Liljeborgia dellavallei (Stebbing, 1906) & $\bullet$ & $\bullet$ & $\bullet$ & $\bullet$ \\
\hline \multicolumn{5}{|l|}{ Lysianassa pilicornis (Heller, 1866) } \\
\hline Lysianassina longicornis (Lucas, 1849) & & $\bullet$ & & - \\
\hline Maera grossimana (Montagu, 1808) & & & • & \\
\hline Microdeutopussp. & & & $\cdot$ & \\
\hline Orchomenehumilis (Costa, 1853) & $\bullet$ & • & & \\
\hline Orchomene similis (Chevreux, 1912) & & • & & \\
\hline Peltocoxa marioni (Catta, 1875) & & • & - & - \\
\hline Siphonoecetes dellavallei (Stebbing, 1899) & & • & - & • \\
\hline Stenothoe monoculoides (Montagu, 1815) & & $\cdot$ & & $\cdot$ \\
\hline Synchelidium longidigitatum (Ruffo, 1947) & & • & & \\
\hline Tmetonyx nardonis (Heller, 1866) & • & $\bullet$ & & • \\
\hline Tritaeta gibbosa (Bate, 1862) & • & & & \\
\hline \multicolumn{5}{|l|}{ Caprellidea } \\
\hline Caprella acanthifera (Leach, 1814) & $\bullet$ & 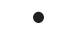 & • & - \\
\hline Caprella sp. (armata-group) (see Krapp-Schickel\& Vader, 1998) & & • & & - \\
\hline Phtisica marina (Slabber, 1769) & - & & ? & - \\
\hline Pseudoprotella phasma (Montagu, 1804) & $\bullet$ & ○ & $\bullet$ & $\bullet$ \\
\hline
\end{tabular}

$\cdot<1 \quad 1-10 \bigcirc 11-50 \bigcirc 51-200$ ind. $\mathrm{m}^{-2}$ 
Table 3

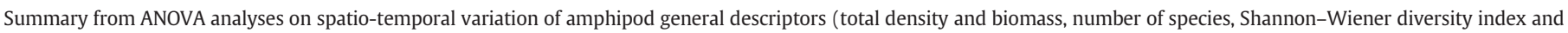
Pielou's evenness), of density of the most frequent amphipod taxa ( $f \geq 10 \%)$, and of biomass of the most important taxa in terms of relative biomass ( $\geq 3 \%$ ).

\begin{tabular}{|c|c|c|c|c|c|c|c|}
\hline & $Y$ & $Z$ & $S(Z)$ & $\operatorname{Se}(S(Z))$ & $Y \times Z$ & $Y \times S(Z)$ & $Y \times \operatorname{Se}(S(Z))$ \\
\hline Total density & ns & ns & ns & ns & ns & ns & $* *$ \\
\hline Total biomass & ns & ns & ns & ns & ns & ns & ns \\
\hline Number of species & $*$ & ns & - & ns & ns & ns & ns \\
\hline Diversity & $*$ & - & ns & ns & ns & ns & ns \\
\hline Evenness & ns & ns & - & ns & ns & ns & ns \\
\hline Gammaridea & $\mathrm{ns} / \mathrm{ns}$ & $\mathrm{ns} / \mathrm{ns}$ & $\mathrm{ns} / \mathrm{ns}$ & $\mathrm{ns} / \mathrm{ns}$ & $\mathrm{ns} / \mathrm{ns}$ & $\mathrm{ns} / \mathrm{ns}$ & $* / \mathrm{ns}$ \\
\hline Ampithoe helleri & ns & ns & ns & ns & ns & ns & ns \\
\hline Aora spinicornis & $\mathrm{ns} / \mathrm{ns}$ & $\mathrm{ns} / \mathrm{ns}$ & $\mathrm{ns} / \mathrm{ns}$ & $\mathrm{ns} / \mathrm{ns}$ & $\mathrm{ns} / \mathrm{ns}$ & $\mathrm{ns} / \mathrm{ns}$ & $\mathrm{ns} / \mathrm{ns}$ \\
\hline Apherusa chiereghinii & $\mathrm{ns} / \mathrm{ns}$ & ns/- & $\mathrm{ns} / \mathrm{ns}$ & $\mathrm{ns} / \mathrm{ns}$ & $\mathrm{ns} / \mathrm{ns}$ & $\mathrm{ns} / \mathrm{ns}$ & ${ }^{* * *} / \mathrm{ns}$ \\
\hline Apolochus neapolitanus & $*$ & ns & ns & ns & ns & ns & ns \\
\hline Dexamine spiniventris & $* * / \mathrm{ns}$ & $-/ \mathrm{ns}$ & ns/- & $\mathrm{ns} / \mathrm{ns}$ & $\mathrm{ns} / \mathrm{ns}$ & $\mathrm{ns} / \mathrm{ns}$ & $\mathrm{ns} / *$ \\
\hline Dexamine spinosa & ns & - & - & ns & ns & ns & ns \\
\hline Ericthonius punctatus & $*$ & ns & - & ns & $*$ & ns & ns \\
\hline Eusiroides dellavallei & ns & - & ns & ns & ns & ns & ns \\
\hline Iphimedia minuta & ns & - & ns & ns & ns & ns & $*$ \\
\hline Leptocheirus guttatus & ns & ns & ns & ns & ns & ns & ns \\
\hline Leucothoe spinicarpa & ns & ns & ns & ns & ns & ns & ns \\
\hline Liljeborgia dellavallei & ns & ns & ns & ns & ns & ns & ns \\
\hline Orchomene humilis & ns & ns & ns & ns & ns & $*$ & ns \\
\hline Caprellidea & $\mathrm{ns} / \mathrm{ns}$ & $\mathrm{ns} / \mathrm{ns}$ & $\mathrm{ns} / \mathrm{ns}$ & $\mathrm{ns} / \mathrm{ns}$ & $\mathrm{ns} / \mathrm{ns}$ & $\mathrm{ns} / \mathrm{ns}$ & $\mathrm{ns} /{ }^{* * *}$ \\
\hline Caprella acanthifera & $*$ & ns & - & ns & ns & ns & ns \\
\hline Caprella sp. (armata-group) & ns & - & ns & ns & ns & ns & $*$ \\
\hline Phtisica marina & $\mathrm{ns} / \mathrm{ns}$ & $\mathrm{ns} / \mathrm{ns}$ & $\mathrm{ns} / \mathrm{ns}$ & $\mathrm{ns} / \mathrm{ns}$ & $\mathrm{ns} / \mathrm{ns}$ & $\mathrm{ns} / \mathrm{ns}$ & $\mathrm{ns} /{ }^{* * *}$ \\
\hline Pseudoprotella phasma & $\mathrm{ns} / \mathrm{ns}$ & $\mathrm{ns} / \mathrm{ns}$ & $\mathrm{ns} / \mathrm{ns}$ & $\mathrm{ns} / \mathrm{ns}$ & $\mathrm{ns} / \mathrm{ns}$ & $\mathrm{ns} / \mathrm{ns}$ & $\mathrm{ns} / \mathrm{ns}$ \\
\hline
\end{tabular}

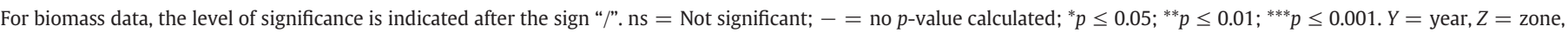
$S=$ site, Se $=$ sector.

was collected in each area and placed in plastic bags, and later quantified as litter biomass ( $\mathrm{g} \mathrm{dw} \mathrm{m}^{-2} ; n=4$ per sector) after drying at $60{ }^{\circ} \mathrm{C}$ for 96 hours. In addition, 3 P. oceanica shoots were collected in each area, for a total of 96 shoots. From these shoots, we calculated leaf and epiphyte biomasses ( $\mathrm{g}$ dw shoot ${ }^{-1} ; n=12$ per sector), as well as coefficient $A$ that refers to the percentage of leaves per shoot with alteration marks (\%; $n=12$ per sector). These alteration marks may be indicative of either in situ consumption of part of the plant by grazers (e.g. the fish Sarpa salpa, the sea urchin Parcentrotus lividus), or hydrodynamic action, especially in shallow sites (Giraud, 1979; Gobert et al., 2003).

\subsection{Data analyses}

\subsubsection{Univariate analyses}

Analysis of variance (ANOVA) was used to examine the effects of the factors year, zone, site and sector on amphipod general descriptors, on the density of the most common species $(f \geq 10 \%)$ and on the biomass of species that accounted for more than $3 \%$ of the total amphipod biomass. The model used was

$$
\begin{aligned}
X_{i j k l m}= & \mu+Y_{i}+Z_{j}+S(Z)_{k(j)}+\operatorname{Se}(S(Z))_{l(k(j))}+Y Z_{i j}+Y S(Z)_{i k(j)} \\
& +Y \operatorname{Se}(S(Z))_{i l(k(j))}+T(Y \operatorname{Se}(S(Z)))_{m(i l(k(j)))}
\end{aligned}
$$

where the site $(S)$ factor was nested within zone $(Z)$, and the sector (Se) factor was nested within site. The year $(Y)$ factor was orthogonal to each scale of sampling (i.e. each scale was sampled every year). All factors were random. $T$ refers to replicates (the error term in the model). $X$ represented each replicate $(\mathrm{m})$ of the dependent variable in any sector $(l)$ and site $(k)$ in a given zone $(j)$ and year $(i) . \mu$ was the overall mean. Table 1 summarizes the structure of the ANOVA and appropriate denominators for $F$-ratios and quasi $F$-ratios (Winer et al., 1991). Satterthwaite's (1946) denominator synthesis method, as implemented in STATISTICA 10 (StatSoft Inc.), was used to calculate error terms in the random-model ANOVA. This method finds the linear combinations of sources of random variation that provide as appropriate error terms and can result in fractional degrees of freedom for the denominator mean square (Satterthwaite, 1946). We used variance component analyses to estimate the proportion of random variation associated with each factor (Searle et al., 1992; Underwood, 1997).

Habitat features available for 2008 were analyzed using a nested analysis of variance (Underwood, 1997) with the following model:

$H_{i j k l}=\mu+Z_{i}+S(Z)_{j(i)}+\operatorname{Se}(S(Z))_{k(j(i))}+T(\operatorname{Se}(S(Z)))_{l(k(j(i)))}$

where zone $(Z)$ was a random factor, the site $(S)$ factor was random and nested within zone, the sector (Se) factor was random and nested within site, and $T$ were the replicates. $H$ represented each replicate (l) of the dependent habitat variable in any sector $(k)$ and site $(j)$ in a given zone (i). $\mu$ was the overall mean.

Prior to these analyses, normality and homogeneity of variances were checked using Kolmogorov-Smirnov's and Cochran's tests respectively. When these assumptions were not met, data were $\sqrt{(x+1)}$ or $\log (x+1)$ transformed. Whenever variances remained heterogeneous, untransformed data were analyzed because ANOVA is statistically robust to heterogeneity of variances, particularly when experiments are balanced and contain a large number of samples (Underwood, 1997). In these cases, special care was taken in the interpretation of results. The significance level was set to 0.05 .

\subsubsection{Multivariate analyses}

Effects of year and different spatial scales on the structure of amphipod assemblages were analyzed as abundance data using a 4-way permutational multivariate analysis of variance (PERMANOVA, Anderson et al., 2008). In the design, all factors (i.e. year, zone, site and sector) were treated as random with 2 levels, with site nested in zone and sector nested in site. The structure of the PERMANOVA is similar to the structure of the random model ANOVA (see Table 1), except the pseudo F-ratios for zone: $\left(\mathrm{MS}_{Z}+\mathrm{MS}_{Y \times S(Z)}\right) /\left(\mathrm{MS}_{S(Z)}+\mathrm{MS}_{Y \times Z}\right)$; and site(zone): $\left(\mathrm{MS}_{S(Z)}+\mathrm{MS}_{Y \times \operatorname{Se}(S(Z))}\right) /\left(\mathrm{MS}_{\mathrm{Se}(S(Z))}+\mathrm{MS}_{Y \times S(Z)}\right)$. Analyses were based on Bray-Curtis dissimilarity matrices calculated from square-root transformed abundance data. Data transformation helped 

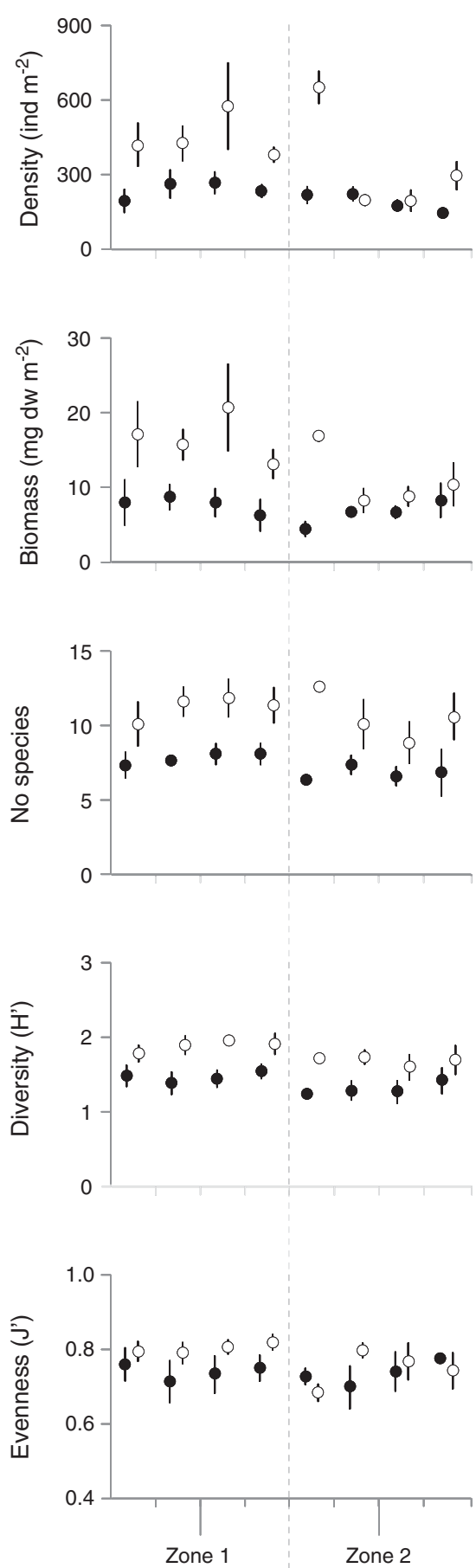

Fig. 2. Mean \pm SE values ( $n=4$ ) of amphipod general descriptors in each sector within each site of the two zones in 2007 (black) and 2008 (white). Descriptors include total amphipod density (number of individuals per $\mathrm{m}^{2}$ ) and biomass ( $\mathrm{mg}$ dry weight per $\mathrm{m}^{2}$ ), and number of species, Shannon-Wiener diversity index $\left(H^{\prime}\right)$ and Pielou's evenness $\left(J^{\prime}\right)$ per sample.

balance the contribution from rarer species. Analyses were run using 9999 random permutations. Permutational test of multivariate dispersion (PERMDISP, Anderson et al., 2008) was used to test the homogeneity of multivariate dispersions.

To visualize multivariate patterns, non-metric multidimensional scaling (nMDS) ordinations were obtained from Bray-Curtis dissimilarity matrices calculated from square-root transformed abundance data. Because of the high number of total samples ( $n=64)$, only the 16 centroids for the combined factor year $\times$ zone $\times$ site $\times$ sector were visualized.

Multiple regression analyses were performed to explore relationships between habitat features (independent variables), and amphipod general descriptors and density of the most common taxa (dependent variables). Prior to regression analyses, data were checked for collinearity and outliers were detected (and subsequently removed) by carrying out analyses of residuals (Graham, 2003; Jongman et al., 1995). The relationships between amphipod assemblages and habitat variables were analyzed using distance-based linear models (DISTLM; Legendre and Anderson, 1999; McArdle and Anderson, 2001). DISTLM performs variation partitioning for sets of explanatory variables, and allows significance testing of explanatory variables for a multivariate response variable in the form of a resemblance matrix (Anderson et al., 2008). Prior to analysis, we tested for collinearity among explanatory variables. The analysis was based on the Bray-Curtis distance measure after square-root transforming the abundance data. The "best" selection procedure, with AIC (Akaikes's information criterion) as the selection criterion based on 9999 permutations was used to test habitat variables. DISTLM analysis was repeated using only significant variables ( $P \leq 0.05$; litter, leaf and epiphyte biomasses). A distancebased redundancy analysis (dbRDA) was performed to visualize the fitted model in 2-dimensional space. Unlike nMDS, this analysis is constrained, meaning that the resulting ordination depends on both species composition and habitat variables. Univariate and multivariate analyses were performed using STATISTICA 10, PRIMER 6 and PERMANOVA + software.

\section{Results}

\subsection{Amphipod assemblages}

The amphipod assemblages represented $22 \%$ of total macrofauna collected. Other major taxa were gastropods $(22 \%)$, asteroids $(12 \%)$, pycnogonids (10\%), decapods ( $8 \%$ ), isopods ( $8 \%$ ) and ostracods (7\%). A total of 3337 amphipod specimens belonging to 36 species and 22 families were identified in this study, of which 13 species occurred in all zones and across sampling years (Table 2). The orders Gammaridea and Caprellidea accounted for $89 \%$ and $11 \%$ of the total number of species respectively, and $83 \%$ and $17 \%$ of the total number of individuals. The families Caprellidae, Dexaminidae, and Lysianassidae contained the highest number of species ( 4 per family). The 3 most frequent species ( $f \geq 80 \%$; Apherusa chiereghinii, Aora spinicornis and Phtisica marina) represented $65 \%$ and $62 \%$ of total abundance and biomass, respectively. Only 5 species were frequent $(40 \% \leq f<80 \%)$ and 9 species common $(10 \% \leq f<40 \%)$, whereas 19 species were occasionally present $(f<10 \%)$. Overall, $9 \%$ of the total specimens were unidentified.

\subsection{Multiscale variation}

Amphipod general descriptors and densities/biomasses of gammarid and caprellid species did not differ significantly across zone ( 1000 m) or site $(\sim 100 \mathrm{~m})$ scales (Table 3; see Appendice Tables A1, A2, A3; Fig. 2). In the different models, the effect of zone and site accounted for only $0-25.6 \%$ and $0-13.3 \%$ of the total variation respectively. In contrast, several occasional or common species were apparently zone specific. Seven species occurred only in zone 1, whereas 6 other species occurred only in zone 2 (Table 2).

The highest spatial heterogeneity occurred at smaller scales. The interaction of year $\times$ sector was significant for the total amphipod density, for 3 species (A. chiereghinii, Iphimedia minuta, Caprella sp. (armata-group)), and was one of the greatest source of variation in the models (25.5\%, $41.0 \%, 21.4 \%$ and $25.7 \%$ respectively). Thus, there was significant spatial variation in the density of these species at 

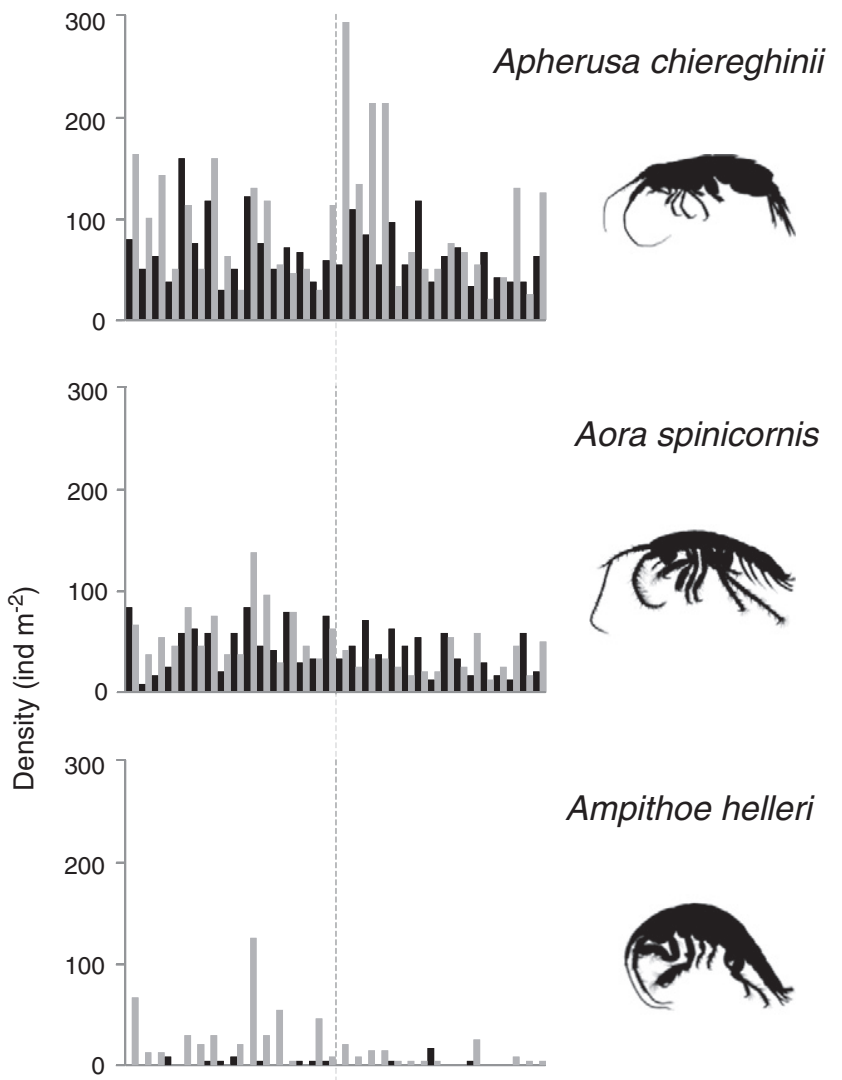

Aora spinicornis

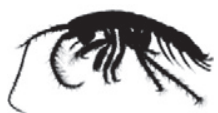

Ampithoe helleri
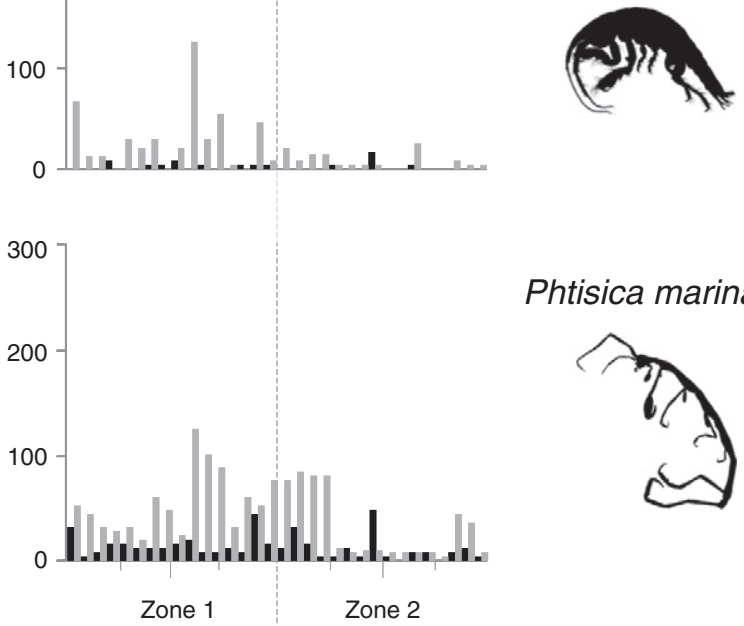

Phtisica marina

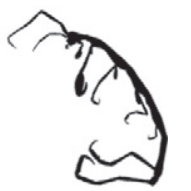

Fig. 3. Density values (number of individuals $\mathrm{m}^{-2}$ ) of the four most abundant species in 2007 (black) and 2008 (grey). Each column refers to a replicate.

the scale of sector, but the nature of this variation varied among years (Table 3; see Appendice Tables A1, A2, A3; Fig. 2). We observed non-significant interaction of year $\times$ sector for some other species, but high magnitude effects (i.e. 37.5\% for Apolochus neapolitanus, $30.6 \%$ for P. marina and $24.8 \%$ for Pseudoprotella phasma; see Appendice Table A2). The variability in species densities seemed important at the spatial scale of $\sim 1 \mathrm{~m}$. Indeed, the most important source of variation in the models was the error term (i.e. samples within sectors at a scale of $\sim 1 \mathrm{~m}$ ) which accounted for 22.6 to $84.2 \%$ of total variation (see Appendice Tables A2, A3; Fig. 3).

The number of species and diversity differed significantly between year, which accounted for the largest component of the variation (Table 3, Fig. 2). At the species level, 3 species (A. neapolitanus, Dexamine spiniventris and Caprella acanthifera) differed significantly between years (Table 3 ). Because of a significant interaction for E. punctatus $(Y \times Z, P=0.012$; Table 3$)$, the effect of the main factor year was not considered for this species (Underwood, 1997).
Table 4

Results from PERMANOVA analysis of amphipod assemblages at the Revellata Bay.

\begin{tabular}{lrrll}
\hline Source & $d f$ & MS & Pseudo- $F$ & $P$ \\
\hline$Y$ & 1 & 7187 & 5.90 & 0.328 \\
$Z$ & 1 & 2946 & 1.73 & 0.210 \\
$S(Z)$ & 2 & 885 & 1.06 & 0.438 \\
$\operatorname{Se}(S(Z))$ & 4 & 839 & 1.15 & 0.374 \\
$Y \times Z$ & 1 & 1218 & 1.78 & 0.235 \\
$Y \times S(Z)$ & 2 & 684 & 0.94 & 0.509 \\
$Y \times \operatorname{Se}(S(Z))$ & 4 & 732 & 1.14 & 0.277 \\
Residual & 48 & 640 & & \\
\hline
\end{tabular}

$d f=$ Degrees of freedom, MS = mean square, pseudo- $F=F$ statistic, $P=$ probability level. $Y=$ year, $Z=$ zone, $S=$ site, $S e=$ sector.

Amphipod biomass results differed somewhat from those for densities (Table 3, see Appendice Table A3). D. spiniventris showed no significant year effect; however density differences were found. Biomasses of Gammaridea, and $A$. chiereghinii were not significant for year $\times$ sector, whereas Caprellidea and P. marina exhibited significant spatial heterogeneity at this scale. As with total amphipod density, the error term represented the most important source of variation in the models (i.e. scale of $\sim 1 \mathrm{~m}$ ). PERMANOVA demonstrated that amphipod assemblage structures did not differ between years, zones, sites and sectors, and there were no significant interactions among these factors (Table 4). In addition, PERMDISP tests showed no significant dispersion effects. General patterns of the nMDS plot reflected PERMANOVA and PERMDISP (Fig. 4) results in that groups of centroids belonging to each zone and year were not clearly separated.

\subsection{Spatial variation of the meadow features}

Nested ANOVA performed on $P$. oceanica variables showed that shoot density, coefficient $A$ and litter biomass did not vary significantly at any spatial scales. In these cases, the error term accounted for 68.2 to $87.5 \%$ of the total variance (Table 5, Fig. 5). Significant differences were detected for leaf biomass at the sector scale (which accounted for $41.0 \%$

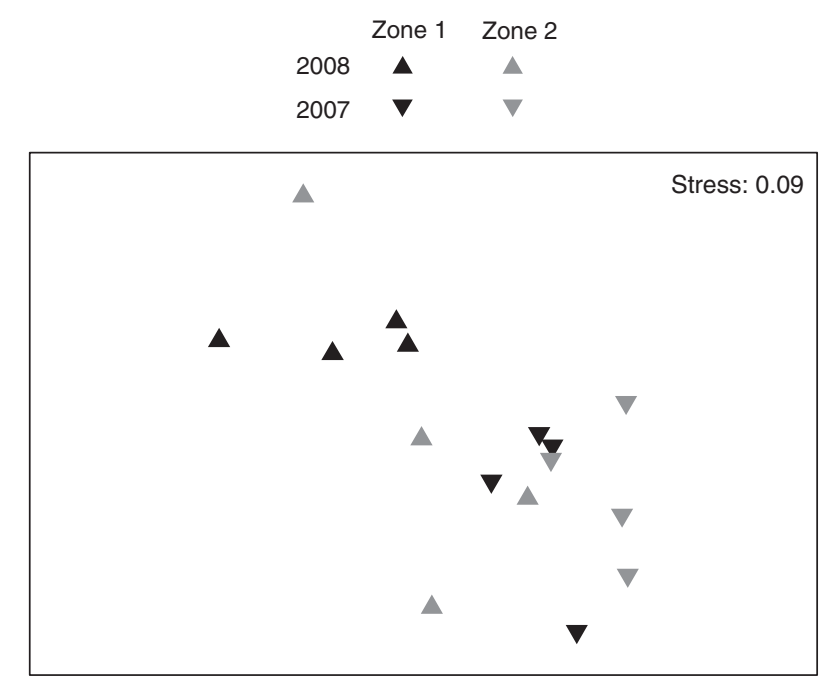

Fig. 4. Non-metric multidimensional scaling (nMDS) ordination of amphipod assemblages. Plot triangles indicate sector centroids, coded by zone and year. The stress value is shown to indicate the goodness of representation. 
Table 5

Results of the nested ANOVA for Posidonia oceanica variables: shoot density, leaf and epiphyte biomasses, coefficient $A$ and litter biomass.

\begin{tabular}{|c|c|c|c|c|c|}
\hline Source & $d f$ & MS & $F$ & $P$ & $\%$ \\
\hline \multicolumn{6}{|c|}{ Shoot density } \\
\hline \multirow[t]{2}{*}{$Z$} & & 110.79 & 0.00 & 0.957 & 0.0 \\
\hline & 1 & $30,230.19$ & 2.41 & 0.205 & 12.5 \\
\hline$S(Z)$ & 2 & & & & \\
\hline \multirow[t]{2}{*}{$\operatorname{Se}(S(Z))$} & & $12,529.91$ & 0.81 & 0.533 & 0.0 \\
\hline & 4 & & & & \\
\hline \multirow[t]{2}{*}{ Residual } & & $15,522.69$ & & & 87.5 \\
\hline & 24 & & & & \\
\hline \multicolumn{6}{|c|}{ Leaf biomass } \\
\hline \multirow[t]{2}{*}{$Z$} & & 0.93 & 6.69 & 0.123 & 33.3 \\
\hline & 1 & & & & \\
\hline \multirow[t]{2}{*}{$S(Z)$} & & 0.14 & 0.49 & 0.644 & 0.0 \\
\hline & 2 & & & & \\
\hline \multirow[t]{2}{*}{$\operatorname{Se}(S(Z))$} & & 0.28 & 7.38 & 0.001 & 41.0 \\
\hline & 4 & & & & \\
\hline \multirow[t]{2}{*}{ Residual } & & 0.04 & & & 25.7 \\
\hline & 24 & & & & \\
\hline \multicolumn{6}{|c|}{ Epiphyte biomass } \\
\hline \multirow[t]{2}{*}{ Z } & & 0.22 & 74.07 & 0.013 & 53.5 \\
\hline & 1 & & & & \\
\hline \multirow[t]{2}{*}{$S(Z)$} & & 0.00 & 0.13 & 0.886 & 0.0 \\
\hline & 2 & & & & \\
\hline \multirow[t]{2}{*}{$\operatorname{Se}(S(Z))$} & & 0.02 & 3.04 & 0.037 & 15.7 \\
\hline & 4 & & & & \\
\hline \multirow[t]{2}{*}{ Residual } & & 0.01 & & & 30.8 \\
\hline & 24 & & & & \\
\hline \multicolumn{6}{|c|}{ Coefficient A } \\
\hline \multirow[t]{2}{*}{$Z$} & & 285.10 & 4.20 & 0.177 & 14.6 \\
\hline & 1 & & & & \\
\hline$S(Z)$ & 2 & 67.81 & 1.92 & 0.260 & 4.4 \\
\hline \multirow[t]{2}{*}{$\operatorname{Se}(S(Z))$} & 2 & 35.24 & 0.47 & 0.758 & 0.0 \\
\hline & 4 & & & & \\
\hline \multirow[t]{2}{*}{ Residual } & & 75.25 & & & 81.0 \\
\hline & 24 & & & & \\
\hline \multicolumn{6}{|c|}{ Litter biomass } \\
\hline \multirow[t]{2}{*}{ Z } & & 1076.84 & 1.52 & 0.343 & 6.7 \\
\hline & 1 & & & & \\
\hline \multirow[t]{2}{*}{$S(Z)$} & & 707.95 & 1.56 & 0.316 & 9.2 \\
\hline & 2 & & & & \\
\hline \multirow[t]{2}{*}{$\operatorname{Se}(S(Z))$} & & 454.73 & 1.93 & 0.138 & 15.9 \\
\hline & 4 & & & & \\
\hline Residual & & 235.28 & & & 68.2 \\
\hline
\end{tabular}

$d f=$ Degrees of freedom, MS $=$ mean square, $F=F$ statistic, $P=$ probability level, $\%=$ percentage of variance explained by each source of variability. $Z=$ zone, $S=$ site, $\mathrm{Se}=$ sector. Significant values are underlined and in bold.

of the total variation), and for epiphyte biomass at the sector and zone scales (which accounted for $15.7 \%$ and $53.5 \%$ of the total variation respectively). Special care should be taken in the interpretation of the results for epiphyte biomass because variances were heterogeneous and could not be stabilized by transformations.

\subsection{Influence of the meadow on amphipod assemblages}

We identified only a few weak significant relationships between amphipod faunal and measured habitat variables using multiple regression analyses (Table 6). The number of species, diversity, and evenness appeared unaffected by the measured habitat variables. In contrast, amphipod total density and biomass were generally positively related with $P$. oceanica shoot density and epiphyte biomass, respectively. The habitat features accounted for only $0-30 \%$ of the
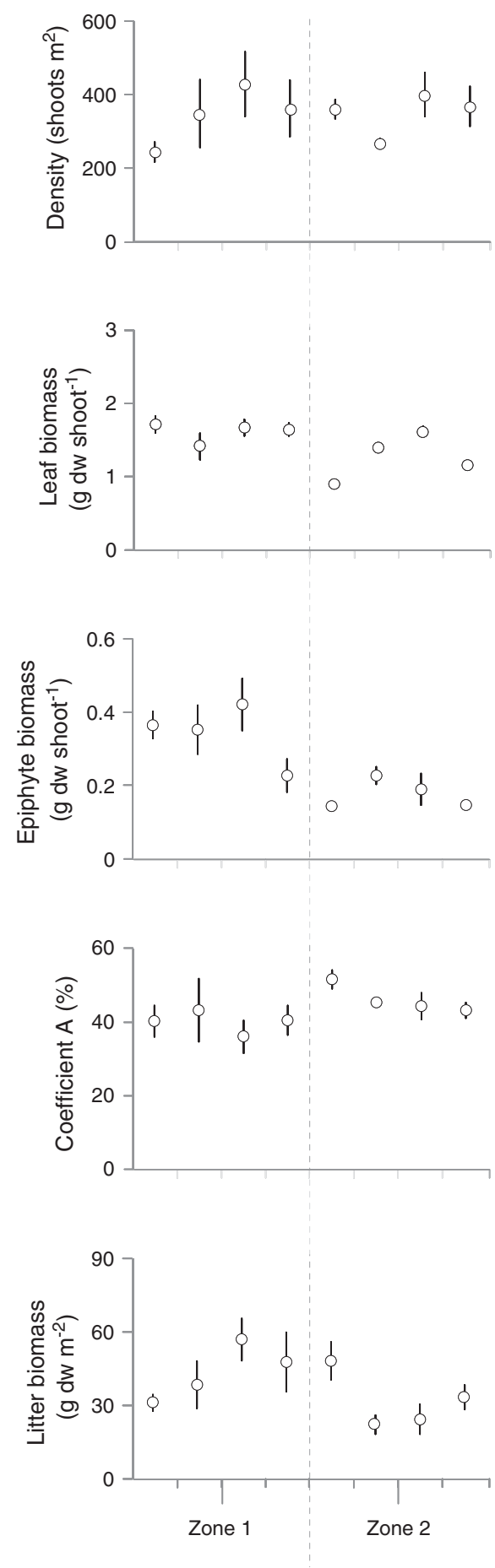

Fig. 5. Mean \pm SE values of Posidonia oceanica shoot density ( shoots $\cdot \mathrm{m}^{-2} ; n=4$ per sector), leaf and epiphyte biomasses ( $\mathrm{g} \mathrm{dw} \cdot \operatorname{shoot}^{-1} ; n=12$ per sector), coefficient $A$ (percentage of leaves per shoot having alteration marks; $n=12$ per sector) and litter biomass ( $\mathrm{g} \mathrm{dw} \cdot \mathrm{m}^{-2} ; n=4$ per sector), in each sector within each site in each zone in 2008.

variation in amphipod species densities. Gammarids were not related to any habitat variables, whereas $P$. oceanica shoot density and coefficient $A$ appeared to have greater influence on caprellids (Table 6). Indeed, densities of the caprellids $P$. marina and $P$. phasma were positively related to $P$. oceanica shoot density $(P C=0.47$ and 
Table 6

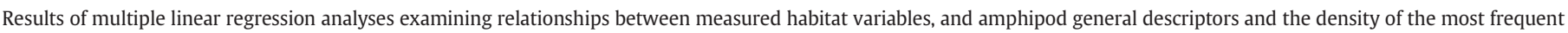

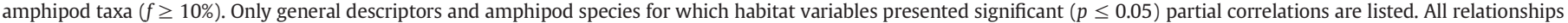
are positive. The overall regression included shoot density, leaf and epiphyte biomasses, coefficient $A$ and litter biomass.

\begin{tabular}{|c|c|c|c|c|c|c|c|c|c|}
\hline & \multicolumn{4}{|c|}{ Overall regression } & \multicolumn{5}{|l|}{ Habitat variable } \\
\hline & $R^{2}$ adj & $P$ & $F$ & $d f$ & & Coef & SE & PC & $P$ \\
\hline Total density & 0.235 & 0.056 & 2.60 & 5.21 & Density & 0.47 & 0.18 & 0.49 & 0.018 \\
\hline Total biomass & 0.116 & 0.183 & 1.68 & 5.21 & Epiphyte biomass & 0.57 & 0.24 & 0.45 & 0.030 \\
\hline \multirow[t]{2}{*}{ Caprellidea } & 0.263 & 0.052 & 2.71 & 5.19 & Density & 0.55 & 0.20 & 0.53 & 0.013 \\
\hline & & & & & Coefficient $A$ & 0.51 & 0.22 & 0.47 & 0.030 \\
\hline \multirow[t]{2}{*}{ Phtisica marina } & 0.174 & 0.123 & 2.01 & 5.19 & Density & 0.50 & 0.21 & 0.47 & 0.032 \\
\hline & & & & & Coefficient $A$ & 0.49 & 0.23 & 0.44 & 0.047 \\
\hline Pseudoprotella phasma & 0.209 & 0.089 & 2.27 & 5.19 & Density & 0.60 & 0.21 & 0.55 & 0.010 \\
\hline
\end{tabular}

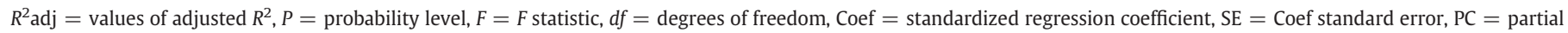
correlation.

0.55 respectively, $P \leq 0.05)$. Density of $P$. marina was also positively associated with coefficient $A$.

The distance-based linear regression model indicated weak relationships between amphipod assemblages and habitat variables. The most parsimonious model contained 3 of the 5 measured habitat variables: litter biomass (pseudo- $F=6.66, P=0.0001$ ), epiphyte biomass (pseudo- $F=2.56, P=0.023$ ) and leaf biomass (pseudo- $F=$ $2.00, P=0.050$ ). This model explained a total of $25.8 \%$ of variation in distribution and abundance of amphipods, with no significant collinearity among habitat variables. The first dbRDA axis accounted for $18.6 \%$ of the total variation in amphipod assemblage and

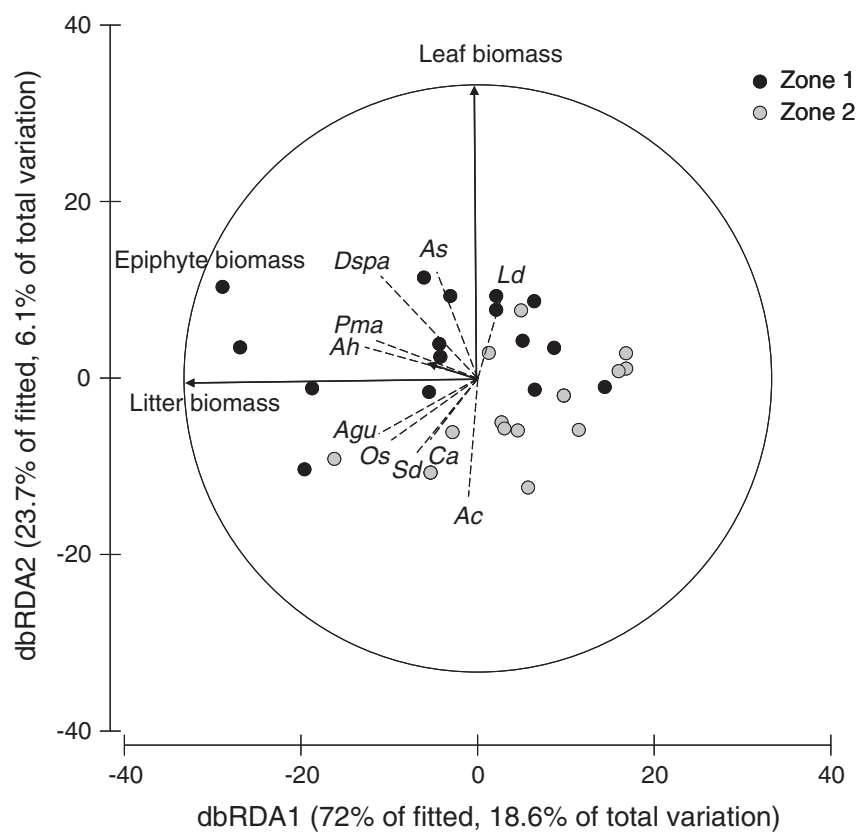

Fig. 6. Distance-based redundancy ordination (dbRDA) for amphipod species and habitat features. Full and indented vectors indicate the direction of increasing values of the significant habitat variables ( $p \leq 0.05$; litter, leaf and epiphyte biomasses) and amphipod species, respectively. Only species with correlations $\geq 0.25$ to the ordination axes are plotted. Vector length represents partial correlation strength with the dbRDA axes; the circle is a unit circle (radius $=1$ ), whose relative size and position of origin is arbitrary with respect to the underlying plot. Plot points indicate individual amphipod samples, coded by zone. Species code: Ah, Ampithoe helleri; As, Aora spinicornis; Ac, Apherusa chiereghinii; Agu, Atylus guttatus; Ca, Caprella acanthifera; Dspa, Dexamine spinosa; Ld, Liljeborgia dellavallei; Os, Orchomene similis; Pma, Phtisica marina; Sd, Siphonoecetes dellavallei. distinguished samples based essentially on litter biomass. The second dbRDA axis accounted for $6.1 \%$ of the variation in amphipod assemblages and discriminated samples based on $P$. oceanica leaf biomass (Fig. 6). All amphipod species (except Liljeborgia dellavallei) had negative values in the first axis, suggesting a positive relationship with litter biomass. Yet $A$. spinicornis, A. chiereghinii and L. dellavallei showed a stronger relationship with the second axis, and consequently with leaf biomass (positive for A. spinicornis and L. dellavallei and negative for A. chiereghinii; Fig. 6). In contrast, zone 1 included samples positively associated with the 3 habitat variables (i.e. litter, leaf and epiphyte biomasses).

\section{Discussion}

The main outcomes of this study are: (1) the occurrence of low variability in density and biomass of most species, and in the structure of amphipod assemblages at the landscape level ( 100 and $1000 \mathrm{~m}$ ) along with large interannual variability in the densities of some species; (2) highest spatial variation in density and biomass of amphipods at the smallest scales ( 1 and $10 \mathrm{~m}$ ); and (3) weak relationships between amphipod faunal and seagrass features.

\subsection{Interannual and landscape patterns}

The density and biomass of most species, and the structure of amphipod assemblages did not vary significantly at the landscape level. These findings may be related to the similarity in general features of the study sites (i.e. depth, adjacent habitats, seagrass variables). At large spatial scales, abundance of invertebrates are unlikely to be strongly related in seagrasses (Bell and Westoby, 1986; Worthington et al., 1992). A study maximizing variation in seagrass cover in the selection of sampling sites, found little influence on macrofaunal abundance (Hovel et al., 2002). However, the effects of landscape structure on macrofaunal abundances tend to be variable and species-specific (Bell et al., 2006; Nakaoka and Toyohara, 2000). Other authors demonstrated a strong effect of different landscape structures (e.g. patch size and adjacent habitats) on the abundance of various species of macrofauna (Gullström et al., 2012; Hovel and Lipcius, 2002; Tanner, 2006; Turner et al., 1999).

Despite strong replication, our sampling design may lack sufficient power given the low number of degrees of freedom for the large spatial scales (Underwood, 1997). As a result, the power of the tests was low and only large differences between zones and sites could have been detected (Balestri et al., 2004). Our analyses include large, though non-significant $\mathrm{F}$ values (e.g. A. spinicornis), while the most important source of variation in the model (excluding the error term) was zone, which accounted for $18.5 \%$ of the total variation. However, for most species, variance component analyses showed a very low 
contribution of zone and site scales ( $<10 \%)$. Future studies aimed at examining landscape spatial patterns on amphipod assemblages in $P$. oceanica meadows would benefit from more than two study zones to ensure statistical power in the analyses (e.g. BenedettiCecchi, 2001a).

Large-scale spatial patterns were consistent between years for most species but may suffer the same sampling design weakness noted for the main effects of zone and site. The significant between-year variation in densities of some amphipod species (e.g. A. neapolitanus, D. spiniventris and C. acanthifera) may be regulated by reproduction and recruitment. Generally, Mediterranean amphipod species exhibit fast growths and relatively short life spans (4-6 months up to 2 years; Bellan-Santini, 1998, 1999; Delgado et al., 2009). High temporal variation in density was previously observed for A. neapolitanus and related to periods of intense reproduction (Leite, 2002). In our study, we observed more ovigerous females of A. neapolitanus in 2007 (59\%) than in 2008 (32\%), suggesting higher reproductive activity in 2007 . However, two snapshots separated by a year do not provide a comprehensive view of temporal variation and the factors affecting it.

\subsection{Small scale spatial variability}

Most species showed the highest variation in density and biomass at the smallest spatial scales. These results confirm those from previous analyses conducted in marine coastal ecosystems which documented considerable small-scale spatial variation in distributions and abundances of macrozoobenthic populations across a wide range of habitats (Benedetti-Cecchi, 2001b; Coleman, 2002; Underwood and Chapman, 1996), including seagrasses (De Biasi et al., 2003). In particular, amphipod assemblages varied most at the meter scale in the macrophyte Sargassum stenophyllum (Tanaka and Leite, 2003) and in soft bottoms (Fernandez-Gonzalez et al., 2013). Processes potentially involved in such patterns include complex sets of local physical and biological interactions (Anderson et al., 2005; Fraschetti et al., 2005).

Seagrass meadows are heterogeneous habitats, consisting of patches and gaps of different sizes (Nakaoka, 2005), especially in P. oceanica ecosystems (Balestri et al., 2003; Gobert et al., 2003; Panayotidis et al., 1981; Zupo et al., 2006). Patchiness of microhabitats (with resources such as food and shelters) may create small-scale variability in population densities (Underwood, 1997). At small to intermediate spatial scales, seagrass habitat features likely explain at least some of the variability in macrofaunal assemblages (Gillanders, 2006). However, our data showed only a few weak relationships between amphipod and measured habitat variables. Although shoot density and litter biomass apparently played a non-negligible role, the two statistical methods (i.e. multiple regressions and distance-based linear model) gave some contradictory results, likely because they are based on different assumptions.

In previous studies, the distribution and diversity of amphipods were both positively correlated with shoot density (Vasapollo, 2009). Moreover, abundances of invertebrates within single beds of seagrass (e.g. plots of $25 \mathrm{~m}^{2}$ ) showed noticeable effects when shoot density was manipulated (Bell and Westoby, 1986). In contrast, other authors showed that variation in density of Zostera capricorni shoots explained very little (generally $\leq 5 \%$ ) of the variation in abundance of individual species of decapods (Worthington et al., 1992). In the Gulf of Naples, no clear link was found between abundance and diversity of amphipods and meadow features (e.g. shoot density), suggesting that other biotic and abiotic factors likely contributed to the observed patterns (Gambi et al., 1992; Mazzella et al., 1989; Scipione et al., 1996).

Trophic resource availability and species-specific behavioral traits of amphipods offer two alternative explanations for these amphipod density patterns. The major available trophic resource was epiphytic macroalgae growing on P. oceanica leaves (Mazzella et al., 1992). These macroalgae are the main dietary components for all dominant amphipod species (Michel, 2011). Our data showed that epiphyte biomass accounted for $20 \%$ of the variation of total amphipod biomass. At small scales, macroalgae present high spatial heterogeneity (Balata et al., 2007; Castejón-Silvo and Terrados, 2012; Pardi et al., 2006), which may therefore influence the variability in biomass of some amphipod species (Zakhama-Sraieb et al., 2011), especially in summer where epiflora biomass is high and may not be limiting (Lepoint et al., 1999).

Behavioral responses to other organisms and/or habitat may influence species distributions (Nakaoka, 2005; Underwood and Chapman, 1996).P. oceanica litter provides a structural habitat as well as potential food sources for multiple amphipod species (Gallmetzer et al., 2005; Lepoint et al., 2006). Some of these species are common to the foliar stratum of the meadow (e.g. A. chiereghinii and A. spinicornis), and migrate vertically, probably to avoid daytime predation (Michel, 2011; Sánchez-Jerez et al., 1999). P. oceanica litter is a highly dynamic environment and can vary spatially (Cebrian and Duarte, 2001). Indeed this feature can affect amphipod assemblages (Como et al., 2008; Sánchez-Jerez et al., 2000). Although we observed no significant variation at any scale, variance component analyses indicate that the smallest scales contributed most to total variation of litter biomass. Our study detected no species-litter biomass relationships with multiple regressions. However, distance-based linear model showed that litter biomass explained $18.6 \%$ of the variation of amphipod assemblages. Thus some seagrass features seemed to influence individual species whereas others acted at the assemblage level.

Biomass produced slightly different results than abundance for some taxa, likely because of the great variety of body sizes among species and age differences at the intraspecific level. For instance, $D$. spiniventris and $P$. marina differed in biomass but not in abundance with respect to year $\times$ sector interaction. These stout species are often large in size (usually $>7 \mathrm{~mm}$ and $10 \mathrm{~mm}$ respectively), potentially leading to size difference between juveniles and adults. These results illustrate the importance of considering both abundance and biomass when exploring spatial patterns of amphipod assemblages.

In conclusion, our study demonstrated that most spatial variability in amphipod density and biomass occurred at small scales ( $\sim 1$ and $10 \mathrm{~m}$ ) in P. oceanica meadows. Multiple processes likely underly these patterns. Seagrass features appeared to contribute only weakly to small-scale patterns. We therefore postulated that behavioral processes were likely significant factors. Small amphipods such as caprellids, which have poor swimming capabilities and can only move over short distances of about $1 \mathrm{~m}$ (Caine, 1979, 1991; Keith, 1971), likely respond to factors at very small scales. Variability in spatial patterns at scales smaller than those investigated (i.e. cm; plant or leaf scales) has not yet been quantified in $P$. oceanica ecosystem and deserves further investigation.

\section{Acknowledgements}

The authors would like to thank the staff of the oceanographic research station STARESO (Calvi, Corsica) for valuable help during field work and all volunteers for field and laboratory assistance. We would like to thank R Biondo (Laboratory of Oceanology, University of Liège, Belgium) for technical assistance, Dr. P. Snelgrove (Department of Ocean Sciences and Biology Department, Memorial University of Newfoundland, Canada) and anonymous referees for their critical comments on the article. This study was supported by the Belgian Fund for Research for the Industry and Agriculture (FRIA, grant no. FC77010), by a Special Research Fund of the University of Liège (FSR), and the Belgian National Fund for Scientific Research (FNRS). This paper is MARE publication number 266. 


\section{Appendix A}

Table A1

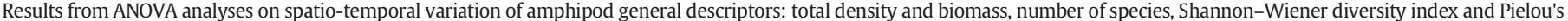
evenness.

\begin{tabular}{|c|c|c|c|c|c|}
\hline Source & $d f$ & MS & $F$ & $P$ & $\%$ \\
\hline \multicolumn{6}{|l|}{ Total density } \\
\hline$Y$ & 1 & 50,6646 & 28.81 & 0.117 & 31.6 \\
\hline$Z$ & 1 & 106,357 & 1.61 & 0.342 & 2.6 \\
\hline$S(Z)$ & 2 & 62,883 & 4.00 & 0.792 & 6.1 \\
\hline $\operatorname{Se}(S(Z))$ & 4 & 66,823 & 1.02 & 0.492 & 0.4 \\
\hline$Y \times Z$ & 1 & 17,587 & 1.23 & 0.383 & 0.4 \\
\hline$Y \times S(Z)$ & 2 & 14,285 & 0.22 & 0.813 & 0.0 \\
\hline$Y \times \operatorname{Se}(S(Z))$ & 4 & 65,373 & 4.05 & 0.007 & 25.5 \\
\hline Residual & 48 & 16,127 & & & 33.4 \\
\hline \multicolumn{6}{|l|}{ Total biomass } \\
\hline$Y$ & 1 & 5.63 & 18.00 & 0.147 & 36.2 \\
\hline$Z$ & 1 & 0.86 & 10.71 & 0.846 & 7.3 \\
\hline$S(Z)$ & 2 & 0.02 & 0.23 & 0.911 & 0.0 \\
\hline $\operatorname{Se}(S(Z))$ & 4 & 0.14 & 0.46 & 0.762 & 0.0 \\
\hline$Y \times Z$ & 1 & 0.31 & 1.24 & 0.381 & 5.7 \\
\hline$Y \times S(Z)$ & 2 & 0.25 & 0.81 & 0.507 & 0.0 \\
\hline$Y \times \operatorname{Se}(S(Z))$ & 4 & 0.31 & 1.65 & 0.177 & 6.5 \\
\hline Residual & 48 & 0.19 & & & 44.4 \\
\hline \multicolumn{6}{|l|}{ No species } \\
\hline$Y$ & 1 & 5.07 & 236.05 & 0.041 & 56.0 \\
\hline$Z$ & 1 & 0.34 & 3.08 & 0.295 & 2.3 \\
\hline$S(Z)$ & 2 & 0.13 & - & - & 2.4 \\
\hline $\operatorname{Se}(S(Z))$ & 4 & 0.05 & 0.51 & 0.734 & 0.0 \\
\hline$Y \times Z$ & 1 & 0.02 & 0.51 & 0.550 & 0.0 \\
\hline$Y \times S(Z)$ & 2 & 0.04 & 0.40 & 0.692 & 0.0 \\
\hline$Y \times \operatorname{Se}(S(Z))$ & 4 & 0.10 & 0.94 & 0.452 & 0.0 \\
\hline Residual & 48 & 0.11 & & & 39.4 \\
\hline \multicolumn{6}{|l|}{ Diversity } \\
\hline$Y$ & 1 & 2.65 & 471.13 & 0.029 & 49.7 \\
\hline$Z$ & 1 & 0.53 & 265.05 & - & 9.9 \\
\hline$S(Z)$ & 2 & 0.02 & 0.91 & 0.563 & 0.0 \\
\hline $\operatorname{Se}(S(Z))$ & 4 & 0.02 & 0.93 & 0.528 & 0.0 \\
\hline$Y \times Z$ & 1 & 0.01 & 0.20 & 0.700 & 0.0 \\
\hline$Y \times S(Z)$ & 2 & 0.03 & 1.57 & 0.313 & 0.8 \\
\hline$Y \times \operatorname{Se}(S(Z))$ & 4 & 0.02 & 0.27 & 0.893 & 0.0 \\
\hline Residual & 48 & 0.07 & & & 39.6 \\
\hline \multicolumn{6}{|l|}{ Evenness } \\
\hline$Y$ & 1 & 0.02 & 2.24 & 0.375 & 5.5 \\
\hline$Z$ & 1 & 0.01 & 1.01 & 0.447 & 0.0 \\
\hline$S(Z)$ & 2 & 0.00 & - & - & 5.8 \\
\hline $\operatorname{Se}(S(Z))$ & 4 & 0.00 & 0.42 & 0.791 & 0.0 \\
\hline$Y \times Z$ & 1 & 0.01 & 8.50 & 0.100 & 7.8 \\
\hline$Y \times S(Z)$ & 2 & 0.00 & 0.19 & 0.835 & 0.0 \\
\hline$Y \times \operatorname{Se}(S(Z))$ & 4 & 0.01 & 1.12 & 0.358 & 2.4 \\
\hline Residual & 48 & 0.01 & & & 78.5 \\
\hline
\end{tabular}

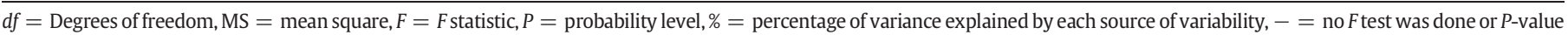
calculated. $Y=$ year, $Z=$ zone, $S=$ site, $S e=$ sector. Significant values are underlined and in bold.

Table A2

Results from ANOVA analyses on spatio-temporal variation of density of the most frequent gammarid (A) and caprellid (B) amphipod taxa ( $f \geq 10 \%)$.

\begin{tabular}{|c|c|c|c|c|c|c|c|c|c|c|c|c|c|}
\hline Source & $d f$ & MS & $F$ & $P$ & $\%$ & MS & $F$ & $P$ & $\%$ & MS & $F$ & $P$ & $\%$ \\
\hline \multicolumn{14}{|l|}{$A$} \\
\hline & & \multicolumn{4}{|l|}{ Gammaridea } & \multicolumn{4}{|c|}{ Ampithoe helleri } & \multicolumn{4}{|c|}{ Aora spinicornis } \\
\hline$Y$ & 1 & $23,1426.19$ & 112.61 & 0.060 & 26.7 & 6813.86 & 2.45 & 0.362 & 14.8 & 0.76 & 0.08 & 0.823 & 0.0 \\
\hline$Z$ & 1 & $43,710.95$ & 1.75 & 0.404 & 2.2 & 3385.87 & 1.15 & 0.465 & 1.6 & 42.18 & 5.45 & 0.391 & 18.5 \\
\hline$S(Z)$ & 2 & $32,884.96$ & 2.81 & 0.718 & 4.9 & 477.94 & 2.09 & 0.795 & 1.8 & 3.87 & 0.50 & 0.644 & 0.0 \\
\hline $\operatorname{Se}(S(Z))$ & 4 & $37,062.82$ & 1.05 & 0.481 & 0.8 & 789.24 & 0.90 & 0.540 & 0.0 & 3.11 & 3.77 & 0.113 & 4.2 \\
\hline$Y \times Z$ & 1 & 2055.05 & 0.21 & 0.693 & 0.0 & 2785.24 & 8.79 & 0.097 & 18.1 & 9.29 & 1.71 & 0.321 & 5.7 \\
\hline$Y \times S(Z)$ & 2 & 9899.87 & 0.28 & 0.769 & 0.0 & 316.80 & 0.36 & 0.717 & 0.0 & 5.43 & 6.58 & 0.054 & 7.0 \\
\hline$Y \times \operatorname{Se}(S(Z))$ & 4 & $35,260.93$ & 3.05 & 0.026 & 22.1 & 877.14 & 2.05 & 0.103 & 13.2 & 0.82 & 0.23 & 0.922 & 0.0 \\
\hline Residual & 48 & $11,577.85$ & & & 43.2 & 428.50 & & & 50.4 & 3.63 & & & 64.6 \\
\hline
\end{tabular}


Table A2 (continued)

\begin{tabular}{|c|c|c|c|c|c|c|c|c|c|c|c|c|c|}
\hline Source & $d f$ & MS & $F$ & $P$ & $\%$ & MS & $F$ & $P$ & $\%$ & MS & $F$ & $P$ & $\%$ \\
\hline & & \multicolumn{4}{|c|}{ Apherusa chiereghinii } & \multicolumn{4}{|c|}{ Apolochus neapolitanus } & \multicolumn{4}{|c|}{ Dexamine spiniventris } \\
\hline$Y$ & 1 & $18,495.47$ & 7.58 & 0.222 & 7.6 & 39.89 & 406.38 & 0.032 & 23.5 & 24.57 & 5155.05 & 0.009 & 12.3 \\
\hline$Z$ & 1 & 103.00 & 0.01 & 0.943 & 0.0 & 3.39 & 0.48 & $\overline{0.649}$ & 0.0 & 15.65 & - & - & 16.4 \\
\hline$S(Z)$ & 2 & $16,305.37$ & 7.13 & 0.847 & 13.3 & 11.07 & 1.83 & 0.343 & 8.0 & 1.17 & 0.61 & 0.633 & 4.6 \\
\hline $\operatorname{Se}(S(Z))$ & 4 & $11,856.49$ & 0.89 & 0.542 & 0.0 & 4.89 & 1.62 & 0.326 & 1.2 & 0.47 & 0.80 & 0.585 & 0.0 \\
\hline$Y \times Z$ & 1 & 2439.60 & 0.66 & 0.501 & 0.0 & 0.10 & 0.02 & 0.892 & 0.0 & 0.00 & 0.00 & 0.966 & 8.5 \\
\hline$Y \times S(Z)$ & 2 & 3682.98 & 0.28 & 0.771 & 0.0 & 4.18 & 1.38 & 0.350 & 3.7 & 2.03 & 3.41 & 0.137 & 0.0 \\
\hline$Y \times \operatorname{Se}(S(Z))$ & 4 & $13,253.69$ & 5.31 & 0.001 & 41.0 & 3.02 & 1.99 & 0.111 & 37.5 & 0.59 & 0.55 & 0.703 & 0.0 \\
\hline \multirow[t]{2}{*}{ Residual } & 48 & 2498.20 & & & 38.1 & 1.52 & & & 26.0 & 1.09 & & & 58.2 \\
\hline & & \multicolumn{4}{|c|}{ Dexamine spinosa } & \multicolumn{4}{|c|}{ Ericthonius punctatus } & \multicolumn{4}{|c|}{ Eusiroides dellavallei } \\
\hline$Y$ & 1 & 22.43 & 1.96 & 0.395 & 0.7 & 17.91 & 302.41 & 0.037 & 0.0 & 0.10 & 0.68 & 0.561 & 33.0 \\
\hline$Z$ & 1 & 385.01 & - & - & 25.6 & 0.06 & 1.00 & $\overline{0.500}$ & 5.8 & 0.73 & - & - & 0.0 \\
\hline$S(Z)$ & 2 & 5.95 & 13.00 & - & 0.7 & 0.00 & 1.00 & - & 0.0 & 0.38 & 0.26 & 0.800 & 0.0 \\
\hline $\operatorname{Se}(S(Z))$ & 4 & 23.35 & 0.44 & 0.775 & 0.0 & 1.66 & 1.00 & 0.500 & 0.0 & 0.77 & 0.96 & 0.515 & 0.0 \\
\hline$Y \times Z$ & 1 & 11.44 & 0.38 & 0.598 & 0.0 & 0.06 & 83.21 & 0.012 & 0.0 & 0.15 & 0.10 & 0.779 & 1.0 \\
\hline$Y \times S(Z)$ & 2 & 29.76 & 0.57 & 0.608 & 0.0 & 0.00 & 0.00 & $\overline{1.000}$ & 10.0 & 1.48 & 1.84 & 0.271 & 0.0 \\
\hline$Y \times \operatorname{Se}(S(Z))$ & 4 & 52.65 & 1.77 & 0.151 & 11.8 & 1.66 & 2.30 & 0.073 & 5.9 & 0.80 & 1.31 & 0.281 & 6.4 \\
\hline \multirow[t]{2}{*}{ Residual } & 48 & 29.76 & & & 61.2 & 0.72 & & & 78.3 & 0.61 & & & 59.6 \\
\hline & & \multicolumn{4}{|c|}{ Iphimedia minuta } & \multicolumn{4}{|c|}{ Leptocheirus guttatus } & \multicolumn{4}{|c|}{ Leucothoe spinicarpa } \\
\hline$Y$ & 1 & 696.31 & 18.78 & 0.144 & 24.2 & 11.44 & 25.00 & 0.126 & 5.9 & 1.83 & 0.11 & 0.795 & 0.0 \\
\hline$Z$ & 1 & 11.44 & - & - & 1.8 & 11.44 & 25.00 & 0.286 & 5.9 & 1.83 & 0.20 & 0.846 & 0.0 \\
\hline$S(Z)$ & 2 & 106.67 & 0.44 & 0.687 & 0.0 & 0.46 & 0.08 & 0.928 & 0.0 & 7.32 & 0.40 & 0.713 & 0.0 \\
\hline $\operatorname{Se}(S(Z))$ & 4 & 158.86 & 1.58 & 0.333 & 8.6 & 6.87 & 5.00 & 0.074 & 11.8 & 11.90 & 1.44 & 0.365 & 6.9 \\
\hline$Y \times Z$ & 1 & 37.08 & 0.20 & 0.696 & 0.0 & 0.46 & 1.00 & 0.423 & 0.0 & 16.48 & 1.13 & 0.400 & 1.7 \\
\hline$Y \times S(Z)$ & 2 & 181.75 & 1.81 & 0.275 & 12.0 & 0.46 & 0.33 & 0.735 & 0.0 & 14.65 & 1.78 & 0.280 & 12.1 \\
\hline$Y \times \operatorname{Se}(S(Z))$ & 4 & 100.26 & 3.67 & 0.011 & 21.4 & 1.37 & 0.31 & 0.870 & 0.0 & 8.24 & 1.93 & 0.121 & 14.9 \\
\hline \multirow[t]{2}{*}{ Residual } & 48 & 27.32 & & & 32.1 & 4.43 & & & 76.3 & 4.27 & & & 64.4 \\
\hline & & \multicolumn{4}{|c|}{ Liljeborgia dellavallei } & \multicolumn{4}{|c|}{ Orchomene humilis } & & & & \\
\hline$Y$ & 1 & 2.11 & 0.43 & 0.632 & 0.0 & 45.78 & 1.00 & 0.500 & 0.0 & & & & \\
\hline$Z$ & 1 & 1.11 & 0.15 & 0.736 & 0.0 & 89.73 & 1.96 & 0.416 & 6.1 & & & & \\
\hline$S(Z)$ & 2 & 2.91 & 2.06 & 0.247 & 5.4 & 16.48 & 0.69 & 0.557 & 0.0 & & & & \\
\hline $\operatorname{Se}(S(Z))$ & 4 & 1.13 & 3.58 & 0.122 & 5.4 & 9.16 & 5.00 & 0.074 & 4.1 & & & & \\
\hline$Y \times Z$ & 1 & 4.95 & 8.32 & 0.102 & 2.4 & 45.78 & 2.78 & 0.238 & 8.2 & & & & \\
\hline$Y \times S(Z)$ & 2 & 0.59 & 1.88 & 0.265 & 2.7 & 16.48 & 9.00 & 0.033 & 8.2 & & & & \\
\hline$Y \times \operatorname{Se}(S(Z))$ & 4 & 0.32 & 0.23 & 0.919 & 0.0 & 1.83 & 0.11 & $\overline{0.978}$ & 0.0 & & & & \\
\hline Residual & 48 & 1.36 & & & 84.2 & 16.48 & & & 73.5 & & & & \\
\hline$B$ & & & & & & & & & & & & & \\
\hline & & Caprellide & & & & Caprelld & hifera & & & Caprel & (armata- & & \\
\hline$Y$ & 1 & 24.92 & 74.11 & 0.074 & 33.1 & 165.26 & 361.00 & 0.033 & 13.9 & 3.51 & 41.75 & 0.098 & 15.8 \\
\hline$Z$ & 1 & 9.48 & 2.45 & 0.261 & 0.5 & 4.12 & 0.13 & $\overline{0.802}$ & 0.0 & 0.08 & 1.00 & - & 0.0 \\
\hline$S(Z)$ & 2 & 3.88 & 4.49 & 0.324 & 9.6 & 51.73 & - & - & 9.3 & 1.28 & 1.00 & 0.530 & 0.0 \\
\hline $\operatorname{Se}(S(Z))$ & 4 & 1.43 & 1.58 & 0.335 & 0.0 & 15.11 & 0.39 & 0.809 & 0.0 & 0.75 & 1.00 & 0.500 & 0.0 \\
\hline$Y \times Z$ & 1 & 0.34 & 0.98 & 0.426 & 4.7 & 0.46 & 0.02 & 0.895 & 0.0 & 0.08 & 0.07 & 0.822 & 0.0 \\
\hline$Y \times S(Z)$ & 2 & 0.34 & 0.38 & 0.708 & 0.0 & 20.60 & 0.53 & 0.625 & 0.0 & 1.28 & 1.71 & 0.291 & 14.0 \\
\hline$Y \times \operatorname{Se}(S(Z))$ & 4 & 0.90 & 1.48 & 0.224 & 27.9 & 38.91 & 1.56 & 0.199 & 9.5 & 0.75 & 3.22 & 0.020 & 25.7 \\
\hline Residual & 48 & 0.61 & & & 24.1 & 24.87 & & & 67.3 & 0.23 & & & 44.4 \\
\hline & & Phtisica mc & & & & Pseudop & phasma & & & & & & \\
\hline$Y$ & 1 & 19.67 & 53.64 & 0.086 & 33.5 & 21.49 & 11.41 & 0.183 & 17.1 & & & & \\
\hline$Z$ & 1 & 10.43 & 2.36 & 0.254 & 0.1 & 6.53 & 3.69 & 0.435 & 0.0 & & & & \\
\hline$S(Z)$ & 2 & 4.19 & 7.56 & 0.467 & 10.3 & 1.43 & 0.28 & 0.774 & 9.4 & & & & \\
\hline $\operatorname{Se}(S(Z))$ & 4 & 1.38 & 1.41 & 0.373 & 0.0 & 5.26 & 3.14 & 0.147 & 0.0 & & & & \\
\hline$Y \times Z$ & 1 & 0.37 & 2.44 & 0.259 & 2.8 & 1.88 & 1.22 & 0.384 & 10.9 & & & & \\
\hline$Y \times S(Z)$ & 2 & 0.15 & 0.15 & 0.862 & 0.0 & 1.54 & 0.92 & 0.468 & 0.0 & & & & \\
\hline$Y \times \operatorname{Se}(S(Z))$ & 4 & 0.98 & 1.86 & 0.132 & 30.6 & 1.67 & 1.53 & 0.208 & 24.8 & & & & \\
\hline Residual & 48 & 0.53 & & & 22.6 & 1.09 & & & 37.8 & & & & \\
\hline
\end{tabular}

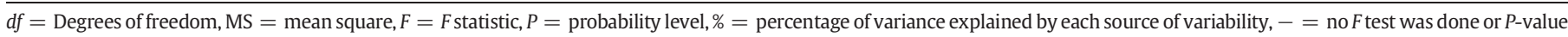
calculated. $Y=$ year, $Z=$ zone, $S=$ site, $S e=$ sector. Significant values are underlined and in bold.

Table A3

Results from ANOVA analyses on spatio-temporal variation of biomass of the most important taxa in terms of relative biomass ( $\geq 3 \%$ ).

\begin{tabular}{|c|c|c|c|c|c|}
\hline Source & $d f$ & MS & $F$ & $P$ & $\%$ \\
\hline \multicolumn{6}{|l|}{ Gammaridea } \\
\hline$Y$ & 1 & 9.60 & 13.88 & 0.167 & 30.3 \\
\hline$Z$ & 1 & 3.16 & 10.22 & 0.680 & 10.6 \\
\hline$S(Z)$ & 2 & 0.23 & 0.59 & 0.731 & 0.0 \\
\hline $\operatorname{Se}(S(Z))$ & 4 & 0.32 & 0.60 & 0.685 & 0.0 \\
\hline$Y \times Z$ & 1 & 0.69 & 1.12 & 0.400 & 3.4 \\
\hline$Y \times S(Z)$ & 2 & 0.62 & 1.13 & 0.408 & 0.3 \\
\hline$Y \times \operatorname{Se}(S(Z))$ & 4 & 0.54 & 1.13 & 0.353 & 0.5 \\
\hline Residual & 48 & 0.48 & & & 54.9 \\
\hline
\end{tabular}


Table A3 (continued)

\begin{tabular}{|c|c|c|c|c|c|}
\hline Source & $d f$ & MS & $F$ & $P$ & $\%$ \\
\hline \multicolumn{6}{|c|}{ Aora spinicornis } \\
\hline$Y$ & 1 & 0.81 & 1.21 & 0.469 & 0.5 \\
\hline$Z$ & 1 & 2.81 & 3.65 & 0.272 & 15.2 \\
\hline$S(Z)$ & 2 & 0.25 & 0.68 & 0.556 & 0.0 \\
\hline $\operatorname{Se}(S(Z))$ & 4 & 0.29 & 3.88 & 0.109 & 6.2 \\
\hline$Y \times Z$ & 1 & 0.67 & 4.52 & 0.167 & 12.6 \\
\hline$Y \times S(Z)$ & 2 & 0.15 & 1.98 & 0.252 & 0.3 \\
\hline$Y \times \operatorname{Se}(S(Z))$ & 4 & 0.07 & 0.34 & 0.850 & 0.0 \\
\hline Residual & 48 & 0.22 & & & 65.2 \\
\hline \multicolumn{6}{|c|}{ Apherusa chiereghinii } \\
\hline$Y$ & 1 & 1.08 & 59.31 & 0.082 & 12.7 \\
\hline$Z$ & 1 & 0.15 & 9.99 & - & 1.8 \\
\hline$S(Z)$ & 2 & 0.26 & 5.27 & 0.923 & 5.8 \\
\hline $\operatorname{Se}(S(Z))$ & 4 & 0.21 & 0.50 & 0.743 & 0.0 \\
\hline$Y \times Z$ & 1 & 0.02 & 0.07 & 0.819 & 0.0 \\
\hline$Y \times S(Z)$ & 2 & 0.27 & 0.62 & 0.583 & 0.0 \\
\hline$Y \times \operatorname{Se}(S(Z))$ & 4 & 0.43 & 2.41 & 0.062 & 31.3 \\
\hline Residual & 48 & 0.18 & & & 48.4 \\
\hline \multicolumn{6}{|c|}{ Dexamine spiniventris } \\
\hline$Y$ & 1 & 2.83 & 8.78 & 0.207 & 6.9 \\
\hline$Z$ & 1 & 0.51 & 7.46 & 0.898 & 2.3 \\
\hline$S(Z)$ & 2 & 0.04 & - & - & 2.3 \\
\hline $\operatorname{Se}(S(Z))$ & 4 & 0.16 & 0.29 & 0.868 & 0.0 \\
\hline$Y \times Z$ & 1 & 0.32 & 1.11 & 0.403 & 2.1 \\
\hline$Y \times S(Z)$ & 2 & 0.29 & 0.52 & 0.628 & 0.0 \\
\hline$Y \times \operatorname{Se}(S(Z))$ & 4 & 0.55 & 2.84 & 0.034 & 20.5 \\
\hline Residual & 48 & 0.20 & & & 65.8 \\
\hline \multicolumn{6}{|l|}{ Caprellidea } \\
\hline$Y$ & 1 & 44.15 & 9.19 & 0.203 & 39.0 \\
\hline$Z$ & 1 & 0.70 & 0.15 & 0.834 & 0.0 \\
\hline$S(Z)$ & 2 & 6.55 & 1.16 & 0.540 & 1.8 \\
\hline $\operatorname{Se}(S(Z))$ & 4 & 3.18 & 0.74 & 0.609 & 0.0 \\
\hline$Y \times Z$ & 1 & 4.81 & 0.71 & 0.488 & 0.0 \\
\hline$Y \times S(Z)$ & 2 & 6.75 & 1.58 & 0.312 & 9.8 \\
\hline$Y \times \operatorname{Se}(S(Z))$ & 4 & 4.27 & 6.54 & 0.000 & 28.7 \\
\hline Residual & 48 & 0.65 & & & 20.7 \\
\hline \multicolumn{6}{|c|}{ Phtisica marina } \\
\hline Y & 1 & 10.55 & 17.73 & 0.148 & 40.8 \\
\hline$Z$ & 1 & 0.01 & 0.05 & 0.969 & 0.0 \\
\hline$S(Z)$ & 2 & 1.15 & 1.35 & 0.630 & 2.4 \\
\hline $\operatorname{Se}(S(Z))$ & 4 & 0.45 & 0.42 & 0.792 & 0.0 \\
\hline$Y \times Z$ & 1 & 0.59 & 0.40 & 0.592 & 0.0 \\
\hline$Y \times S(Z)$ & 2 & 1.49 & 1.36 & 0.354 & 6.5 \\
\hline$Y \times \operatorname{Se}(S(Z))$ & 4 & 1.09 & 7.46 & 0.000 & 31.0 \\
\hline Residual & 48 & 0.15 & & & 19.2 \\
\hline \multicolumn{6}{|c|}{ Pseudoprotella phasma } \\
\hline$Y$ & 1 & 3.88 & 3.11 & 0.328 & 23.3 \\
\hline$Z$ & 1 & 0.30 & 0.24 & 0.725 & 0.0 \\
\hline$S(Z)$ & 2 & 0.64 & 0.91 & 0.526 & 0.0 \\
\hline $\operatorname{Se}(S(Z))$ & 4 & 0.36 & 1.24 & 0.421 & 2.5 \\
\hline$Y \times Z$ & 1 & 1.25 & 1.98 & 0.295 & 10.9 \\
\hline$Y \times S(Z)$ & 2 & 0.63 & 2.15 & 0.232 & 12.0 \\
\hline$Y \times \operatorname{Se}(S(Z))$ & 4 & 0.29 & 2.03 & 0.106 & 10.5 \\
\hline Residual & 48 & 0.14 & & & 40.9 \\
\hline
\end{tabular}

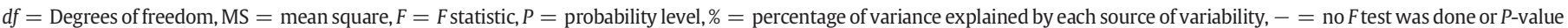
calculated. $Y=$ year, $Z=$ zone, $S=$ site, Se = sector. Significant values are underlined and in bold.

\section{References}

Allen, T.F.H., Hoekstra, T.W., 1991. Role of heterogeneity in scaling of ecological systems under analysis. In: Kolasa, J., Pickett, S.T.A. (Eds.), Ecological Heterogeneity. Springer-Verlag, New York Berlin Heidelberg, pp. 47-68.

Anderson, M.J., Connell, S.D., Gillanders, M.B., Diebel, C.E., Blom, W.M., Saunders, J.E., Lander, T.J., 2005. Relationships between taxonomic resolution and spatial scales of multivariate variation. J. Anim. Ecol. 74, 636-646.

Anderson, M.J., Gorley, R.N., Clarke, K.R., 2008. PERMANOVA + for PRIMER: guide to software and statistical methods. PRIMER-E, Plymouth.

Attrill, M.J., Strong, J.A., Rowden, A.A., 2000. Are macroinvertebrate communities influenced by seagrass structural complexity? Ecography 23, 114-121.

Balata, D., Nesti, U., Piazzi, L., Cinelli, F., 2007. Patterns of spatial variability of seagrass epiphytes in the north-west Mediterranean Sea. Mar. Biol. 151, 2025-2035.
Balestri, E., Cinelli, F., Lardicci, C., 2003. Spatial variation in Posidonia oceanica structural, morphological and dynamic features in a northwestern Mediterranean coastal area: a multi-scale analysis. Mar. Ecol. Prog. Ser. 250, 51-60.

Balestri, E., Benedetti-Cecchi, L., Lardicci, C., 2004. Variability in patterns of growth and morphology of Posidonia oceanica exposed to urban and industrial wastes: contrasts with two reference locations. J. Exp. Mar. Biol. Ecol. 308, 1-21.

Bell, J.D., Harmelin-Vivien, M.L., 1983. Fish fauna of French Mediterranean Posidonia oceanica seagrass meadows, 2 Feeding habits. Tethys 11, 1-14.

Bell, J.D., Westoby, M., 1986. Variation in seagrass height and density over a wide spatial scale: effects on fish and decapods. J. Exp. Mar. Biol. Ecol. 104, 275-295.

Bell, S., Fonseca, M.S., Stafford, N.B., 2006. Seagrass ecology: new contributions from a landscape perspective. In: Larkum, A.W.D., Orth, R.J., Duarte, C.M. (Eds.), Seagrasses: Biology, Ecology and Conservation. Springer, Dordrecht, pp. 625-645.

Bellan-Santini, D., 1998. Ecology. In: Ruffo, S. (Ed.), The Amphipoda of the Mediterranean. Part 4. Mémoires de l'Institut océanographique n¹3, Monaco, pp. 869-893. 
Bellan-Santini, D., 1999. Ordre des Amphipodes (Amphipoda Latreille, 1816). In: Forest, J. et al. (Eds.), Traité de zoologie: anatomie, systématique, biologie: 7. Crustacés: 3A Péracarides. Mémoires de l'Institut océanographique n¹9, Monaco, pp. 93-176.

Benedetti-Cecchi, L., 2001a. Beyond BACI: optimization of environmental sampling designs through monitoring and simulation. Ecol. Appl. 11, 783-799.

Benedetti-Cecchi, L., 2001b. Variability in abundance of algae and invertebrates at different spatial scales on rocky sea shores. Mar. Ecol. Prog. Ser. 215, 79-92.

Boudouresque, C.F., Bernard, G., Bonhomme, P., Charbonnel, E., Diviacco, G., Meinesz, A. Pergent, G., Pergent-Martini, C., Ruitton, S., Tunesi, L., 2006. Préservation et Conservation des Herbiers à Posidonia oceanica. Ramoge, Marseille.

Bussers, J.C., Poulicek, M., Diepvints, J., 1983. Description d'une suceuse à air comprimé économique et utilisable par un seul plongeur. Cah. Biol. Mar. 24, 215-217.

Caine, E.A., 1979. Population structures of two species of caprellid amphipods (Crustacea). J. Exp. Mar. Biol. Ecol. 40, 103-114.

Caine, E.A., 1991. Caprellid amphipods: fast food for the reproductively active. J. Exp. Mar. Biol. Ecol. 148, 27-33.

Castejón-Silvo, I., Terrados, J., 2012. Patterns of spatial variation of nutrient content, epiphyte load and shoot size of Posidonia oceanica seagrass meadows (Mediterranean Sea). Mar. Ecol. 33, 165-175.

Cebrian, J., Duarte, C.M., 2001. Detrital stocks and dynamics of the seagrass Posidonia oceanica (L.) Delile in the Spanish Mediterranean. Aquat. Bot. 70, 295-309.

Coleman, M.A., 2002. Small-scale spatial variability in intertidal and subtidal turfing algal assemblages and the temporal generality of these patterns. J. Exp. Mar. Biol. Ecol. 267, 53-74.

Como, S., Magni, P., Baroli, M., Casu, D., De Falco, G., Floris, A., 2008. Comparative analysis of macrofaunal species richness and composition in Posidonia oceanica, Cymodoced nodosa and leaf litter beds. Mar. Biol. 153, 1087-1101.

Conlan, K.E., 1994. Amphipod crustaceans and environmental disturbance: a review. J. Nat. Hist. 28, 519-554.

Connolly, R.M., 1995. Effects of removal of seagrass canopy on assemblages of small, motile invertebrates. Mar. Ecol. Prog. Ser. 118, 129-137.

Conradi, M., López-González, P.J., García-Gómez, J.C., 1997. The amphipod community as a bioindicator in Algeciras Bay (Southern Iberian Peninsula) based on a spatiotemporal distribution. P.S.Z.N. Mar. Ecol. 18, 97-111.

Dayton, P., Tegner, M.J., 1984. The importance of scale in community ecology: a kelp forest example with terrestrial analogs. In: Price, P.W., Slobodchikoff, C.N., Gaud, W.S. (Eds. ), A New Ecology. Novel Approaches to Interactive Systems. John Wiley \& Sons, New York, pp. 457-481.

De Biasi, A.M., Benedetti-Cecchi, L., Pacciardi, L., Maggi, E., Vaselli, S., Bertocci, I., 2003. Spatial heterogeneity in the distribution of plants and benthic invertebrates in the lagoon of Orbetello (Italy). Oceanol. Acta 26, 39-46.

Delgado, L., Guerao, G., Ribera, C., 2009. The Gammaridea (Amphipoda) fauna in a Mediterranean coastal lagoon: considerations on population structure and reproductive biology. Crustaceana 82, 191-218.

EC, 1992. Council Directive 92/43/EEC of 21 May 1992 on the conservation of natural habitats and of wild fauna and flora. O. J. L. 206 pp. 7-50.

Edgar, G.J., Robertson, A.I., 1992. The influence of seagrass structure on the distribution and abundance of mobile epifauna: pattern and process in a Western Autralian Amphibolis bed. J. Exp. Mar. Biol. Ecol. 160, 13-31.

Fernandez-Gonzalez, V., Aguado-Giménez, F., Gairin, J.I., Sanchez-Jerez, P., 2013. Exploring patterns of variation in amphipod assemblages at multiple spatial scales: natural variability versus coastal aquaculture effect. Aquac. Environ. Interact. 3, 93-105.

Fraschetti, S., Terlizzi, A., Bussotti, S., Guarnieri, G., D'Ambrosio, P., Boero, F., 2005. Conservation of Mediterranean seascapes: analyses of existing protection schemes. Mar. Environ. Res. 59, 309-332.

Gallmetzer, I., Pflugfelder, B., Zekely, J., Ott, J.A., 2005. Macrofauna diversity in Posidonia oceanica detritus: distribution and diversity of mobile macrofauna in shallow sublittoral accumulations of Posidonia oceanica detritus. Mar. Biol. 147, 517-523.

Gambi, M.C., Lorenti, M., Russo, G.F., Scipione, M.B., Zupo, V., 1992. Depth and seasonal distribution of some groups of the vagile fauna of the Posidonia oceanica leaf stratum: structural and trophic analyses. Mar. Ecol. 13, 17-39.

García-Charton, J.A., Pérez-Ruzafa, A., Sánchez-Jerez, P., Bayle-Sempere, J.T., Reñones, O., Moreno-Lampreave, D., 2004. Multi-scale spatial heterogeneity, habitat structure, and the effect of marine reserves on Western Mediterranean rocky reef fish assemblages. Mar. Biol. 144, 161-182.

Gillanders, B.M., 2006. Seagrasses, fish, and fisheries. In: Larkum, A.W.D., Orth, R.J., Duarte, C.M. (Eds.), Seagrasses: Biology, Ecology and Conservation. Springer, Dordrecht, pp. 503-536.

Giraud, G., 1979. Sur une méthode de mesure et de comptage des structures foliaires de Posidonia oceanica (Linnaeus) Delile. Bull. Mus. Hist. Nat. Marseille 39, 33-39.

Gobert, S., 2002. Variations spatiale et temporelle de l'herbier à Posidonia oceanica (L.) Delile (Baie de la Revellata - Calvi - Corse). PhD dissertation , University of Liège, Liège.

Gobert, S., Kyramarios, M., Lepoint, G., Pergent-Martini, C., Bouquegneau, J.M., 2003. Variations at different spatial scales of Posidonia oceanica (L) Delile beds; effects on the physico-chemical parameters of the sediment. Oceanol. Acta 26, 199-207.

Gobert, S., Sartoretto, S., Rico-Raimondino, V., Andral, B., Chery, A., Lejeune, P., Boissery, P., 2009. Assessment of the ecological status of Mediterranean French coastal waters as required by the Water Framework Directive using the Posidonia oceanica Rapid Easy Index: PREI. Mar. Pollut. Bull. 58, 1727-1733.

González, A.R., Guerra-García, J.M., Maestre, M.J., Ruiz-Tabares, A., Espinosa, F., Gordillo, I., Sánchez-Moyano, J.E., García-Gómez, J.C., 2008. Community structure of caprellids (Crustacea: Amphipoda: Caprellidae) on seagrasses from southern Spain. Helgol. Mar. Res. 62, 189-199.

Graham, M.H., 2003. Confronting multicollinearity in ecological multiple regression. Ecology 84, 2809-2815.
Guerra-García, J.M., García-Gómez, J.C., 2001. The spatial distribution of Caprellidea (Crustacea: Amphipoda): a stress bioindicator in Ceuta (North Africa, Gibraltar area). P.S.Z.N. I Mar. Ecol. 22, 357-367.

Gullström, M., Baden, S., Lindegarth, M., 2012. Spatial patterns and environmental correlates in epiphytic assemblages of temperate seagrass (Zostera marina) meadows. Mar. Biol. 159, 413-425

Hovel, K.A., Lipcius, R.N., 2002. Effects of seagrass habitat fragmentation on juvenile blue crab survival and abundance. J. Exp. Mar. Biol. Ecol. 271, 75-98.

Hovel, K.A., Fonseca, M.S., Meyer, D.L., Kenworthy, W.J., Whitfield, P.E., 2002. Effects of seagrass landscape structure, structural complexity, and hydrodynamic regime on macrofaunal densities in North Carolina seagrass beds. Mar. Ecol. Prog. Ser. 243, $11-24$.

Janssens, M., 2000. Etude in situ de la production primaire des macroalgues d'une baie méditerranéenne et influences dans le cycle du carbone. $\mathrm{PhD}$ dissertation, University of Liège, Liège.

Jongman, R.H.G., ter Braak, C.J.F., van Tongeren, O.F.R., 1995. Data Analysis in Community and Landscape Ecology. Cambridge University Press, Cambridge.

Keith, D.E., 1971. Substrate selection in caprellid amphipods of Southern California, with emphasis on Caprella califórnica Stimpson and Caprella equilibra Say (Amphipoda). Pac. Sci. 25, 387-394

Kolasa, J., Pickett, S.T.A., 1991. Ecological Heterogeneity. Ecological Studies 86. SpringerVerlag, New York Berlin Heidelberg.

Legendre, P., Anderson, M.J., 1999. Distance-based redundancy analysis: testing multispecies responses in multifactorial ecological experiments. Ecol. Monogr. 69, 1-24.

Leite, F.P.P., 2002. Life cycle observations on Amphilocus neapolitanus (Della Valle, 1853) (Crustacea, Amphipoda) associated with Sargassum cymosum C. Agardh, 1820 in Ubatuba (SP) Brazil. Braz. Arch. Biol. Technol. 45, 355-363.

Lepoint, G., Havelange, S., Gobert, S., Bouquegneau, J.M., 1999. Fauna vs flora contribution to the leaf epiphytes biomass in a Posidonia oceanica seagrass bed (Revellata Bay, Corsica). Hydrobiologia 394, 63-67.

Lepoint, G., Nyssen, F., Gobert, S., Dauby, P., Bouquegneau, J.M., 2000. Relative impact of a seagrass bed and its adjacent epilithic algal community in consumer diets. Mar. Biol. 136, 513-518.

Lepoint, G., Cox, A.S., Dauby, P., Poulicek, M., Gobert, S., 2006. Food sources of two detritivore amphipods associated with the seagrass Posidonia oceanica leaf litter. Mar Biol. Res. 2, 355-365.

Levin, S.A., 1992. The problem of pattern and scale in ecology. Ecology 73, 1943-1967.

Mazzella, L., Scipione, M.B., Buia, M.C., 1989. Spatio-temporal distribution of algal and animal communities in a Posidonia oceanica meadow. P.S.Z.N Mar. Ecol. 10, 107-129.

Mazzella, L., Buia, M.C., Gambi, M.C., Lorenti, M., Russo, G.F., Scipione, M.B., Zupo, V., 165-187, 1992. Plant-animal trophic relationships in the Posidonia oceanica ecosystem of the Mediterranean Sea: a review. In: John, D.M., Hawkins, S.J., Price, J. H. (Eds.), Plant-Animal Interactions in the Marine Benthos, pp. 165-187.

McArdle, B.H., Anderson, M.J., 2001. Fitting multivariate models to community data: a comment on distance-based redundancy analysis. Ecology 82, 290-297.

Menge, B.A., Farrell, T.M., 1989. Community structure and interaction webs in shallow marine hard-bottom communities: tests of an environmental stress model. Adv. Ecol. Res. 19, 189-262.

Michel, L., 2011. Multidisciplinary study of trophic diversity and functional role of amphipod crustaceans associated to Posidonia oceanica meadows. PhD dissertation , University of Liège, Liège.

Michel, L., Lepoint, G., Dauby, P., Sturaro, N., 2010. Sampling methods for amphipods of Posidonia oceanica meadows: a comparative study. Crustaceana 83, 39-47.

Nakaoka, M., 2005. Plant-animal interactions in seagrass beds: ongoing and future challenges for understanding population and community dynamics. Popul. Ecol. 47 $167-177$.

Nakaoka, M., Toyohara, T., 2000. Effects of seagrass patch structure on the mobile epifaunal community in a subtidal seagrass meadow in Thailand. Benthos Res. 55 53-61.

Panayotidis, P., Boudouresque, C.F., Marcot-Coqueugniot, J., 1981. Microstructure de l'herbier de Posidonia oceanica (Linnaeus) Delile. Bot. Mar. 24, 115-124.

Pardi, G., Piazzi, L., Balata, D., Papi, I., Cinelli, F., Benedetti-Cecchi, L., 2006. Spatial variability of Posidonia oceanica (L) Delile epiphytes around the mainland and the islands of Sicily (Mediterranean Sea). Mar. Ecol. 27, 397-403.

Pasqualini, V., 1997. Caractérisation des peuplements et types de fonds le long du littoral corse (Méditerranée, France). PhD dissertation , University of Corsica, Corte.

Pinnegar, J.K., Polunin, N.V.C., 2000. Contributions of stable-isotope data to elucidating food webs of Mediterranean rocky littoral fishes. Oecologia 122, 399-409.

Ruffo, S., Bellan-Santini, D., Karaman, G., Krapp-Schickel, G., Ledoyer, M., Myers, A. Schiecke, U., 1982. Part 1: Gammaridea (Acanthonozomatidae to Gammaridae). In: Ruffo, S. (Ed.), The Amphipoda of the Mediterranean, Mém. Inst. Oceanogr., Monaco, pp. 1-364.

Ruffo, S., Bellan-Santini, D., Diviacco, G., Krapp-Schickel, G., Myers, A.A., 1989. Part 2 Gammaridea (Haustoridae to Lysianassidae). In: Ruffo, S. (Ed.), The Amphipoda of the Mediterranean, Mém. Inst. Oceanogr., Monaco, pp. 365-576.

Ruffo, S., Bellan-Santini, D., Karaman, G., Krapp-Schickel, G., Ledoyer, M., 1993. Part $3:$ Gammaridea (Melphidippidae to Talitridae), Ingolfiellidea, Caprellidea. In: Ruffo, S (Ed.), The Amphipoda of the Mediterranean, Mém. Inst. Oceanogr., Monaco, pp. 577-813.

Ruffo, S., Bellan-Santini, D., Karaman, G., Ledoyer, M., Myers, A.A., Vader, W., 1998. Part 4: localities and map, addenda to parts 1-3, key to families, ecology, faunistics and zoogeography, bibliography \& index. The Amphipoda of the Mediterranean, Mém. Inst Oceanogr., Monaco, pp. 814-959.

Sánchez-Jerez, P., Barberá-Cebrián, C., Ramos-Esplá, A.A., 1999. Daily vertical migrations in the epifauna associated with Posidonia oceanica meadows. J. Mar. Biol. Assoc. UK 79, 971-977. 
Sánchez-Jerez, P., Barberá-Cebrian, C., Ramos-Esplá, A.A., 2000. Influence of the structure of Posidonia oceanica meadows modified by bottom trawling on crustacean assemblages: comparison of amphipods and decapods. Sci. Mar. 64, 319-326.

Sargian, P., 1997. Contribution à la cartographie de la bande rocheuse infralittorale et de l'herbier à Posidonia oceanica dans la Baie de la Revellata (Calvi). Master thesis in Sciences and techniques, University of Corsica, Corte.

Satterthwaite, F.E., 1946. An approximate distribution of estimates of variance components. Biom. Bull. 2, 110-114.

Schneider, D.C., 1994. Quantitative Ecology: Spatial and Temporal Scaling. Academic Press, San Diego.

Schneider, F.I., Mann, K.H., 1991. Species specific relationships of invertebrates to vegetation in a seagrass bed. II. Experiments on the importance of macrophyte shape, epiphyte cover and predation. J. Exp. Mar. Biol. Ecol. 145, 119-139.

Scipione, M.B., Fresi, E., 1984. Distribution of amphipods crustaceans in Posidonia oceanica (L) Delile foliar stratum. In: Boudouresque, C.F., Jeudy De Grissac, A., Olivier, J. (Eds.), First International Workshop on Posidonia oceanica Beds. GIS Posidonie Publ. Marseille, pp. 319-329.

Scipione, M.B., Gambi, M.C., Lorenti, M., Russo, G.F., Zupo, V., 1996. Vagile fauna of the leaf stratum of Posidonia oceanica and Cymodocea nodosa in the Mediterranean Sea. In: Kuo, J., Phillips, R.C., Walker, D.I., Kirkman, H. (Eds.), Seagrass Biology: Proceedings on an International Workshop. Rottnest Island, Western Australia, pp. 249-260.

Searle, S.R., Cassella, G., McCulloch, C., 1992. Variance Components. Wiley, New York.

Tanaka, M.O., Leite, P.P., 2003. Spatial scaling in the distribution of macrofauna associated with Sargassum stenophyllum (Mertens) Martius: analyses of faunal groups, gammarid life habits, and assemblage structure. J. Exp. Mar. Biol. Ecol. 293, 1-22.

Tanner, J.E., 2006. Landscape ecology of interactions between seagrass and mobile epifauna: the matrix matters. Estuar. Coast. Shelf Sci. 68, 404-412.

Thomas, J.D., 1993. Biological monitoring and tropical biodiversity in marine environments: a critique with recommendations, and comments on the use of amphipods as bioindicators. J. Nat. Hist. 27, 795-806.
Turner, S.J., Hewitt, J.E., Wilkinson, M.R., Morrisey, D.J., Thrush, S.F., Cummings, V.J., Funnel, G., 1999. Seagrass patches and landscape: the influence of wind-wave dynamics and hierarchical arrangements of spatial structure on macrofaunal seagrass communities. Estuaries 22, 1016-1032.

Underwood, A.J., 1997. Experiments in Ecology. Cambridge University Press, Cambridge.

Underwood, A.J., Chapman, M.G., 1996. Scales of spatial patterns of distribution of intertidal invertebrates. Oecologia 107, 212-224.

Vasapollo, C. 2009. Spatio-temporal variability of plant features and motile invertebrates in Posidonia oceanica seagrass meadows. PhD dissertation , The Open University, Milton Keynes.

Vizzini, S., Sarà, G., Michener, R.H., Mazzola, A., 2002. The role and contribution of the seagrass Posidonia oceanica (L) Delile organic matter for secondary consumers as revealed by carbon and nitrogen stable isotope analysis. Acta Oecol. 23, 277-285.

Wiens, J.A., 1989. Spatial scaling in ecology. Funct. Ecol. 3, 385-397.

Winer, B.J., Brown, D.R., Michels, K.M., 1991. Statistical Principles in Experimental Design. McGraw-Hill, New York.

Worthington, D.G., Ferrell, D.J., McNeill, S.E., Bell, J.D., 1992. Effects of the shoot density of seagrass on fish and decapods: are correlations evident over larger spatial scales? Mar. Biol. 112, 139-146.

Zakhama-Sraieb, R., Ramzi Sghaier, Y., Charfi-Cheikhrouha, F., 2011. Community structure of amphipods on shallow Posidonia oceanica meadows off Tunisian coasts. Helgol. Mar. Res. 65, 203-209.

Zupo, V., Mazzella, L., Buia, M.C., Gambi, M.C., Lorenti, M., Scipione, M.B., Cancemi, G., 2006. A small-scale analysis of the spatial structure of a Posidonia oceanica meadow off the Island of Ischia (Gulf of Naples, Italy): relationship with the seafloor morphology. Aquat. Bot. 84, 101-109. 